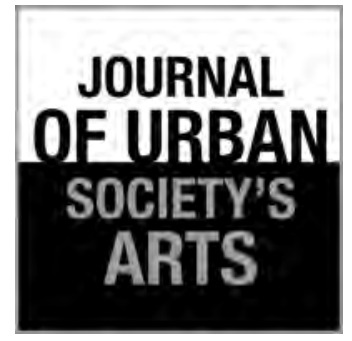

Volume 2 Nomor 1, April 2015: 35-54

\section{Mengapa Selalu Harus Perempuan: Suatu Konstruksi Urban Pemenjaraan Seksual Hingga Hegemoni Maskulinitas dalam Film Soekarno}

\section{Bambang Aris Kartika}

Fakultas Sastra, Universitas Jember

E-mail: bamsliverpudlian@gmail.com; HP: 081578981991

\section{ABSTRAK}

Film Soekarno karya Hanung Bramantyo menghadirkan suatu deksripsi tentang fakta-fakta historis terkait dengan perempuan Indonesia yang dikomodifikasi menjadi teks-teks naratif dan visual film. Wujud representasi dari komodifikasi fakta historis perempuan Indonesia, ditampilkan dalam konstruk urban mengenai visualisasi ketidakadilan gender dalam praktik-praktik politik seksual, kekerasan seksual, kekerasan psikis, hingga pemenjaraan seksual yang diakibatkan oleh hegemoni kolonialisme fasisme Jepang melalui praktik perbudakan seksual (jugun ianfu) dan tokoh Soekarno terhadap diri tokoh Inggit Ganarsih. Makna-makna simbolik dari unsur naratif dan visualisasi yang dihadirkan dalam film Soekarno merupakan suatu strategi kebudayaan dan politik media untuk menjadikan film sebagai media historical memory dan collective memory bagi masyarakat Indonesia untuk melawan lupa dari deskripsi narasi besar sejarah bangsa dan negara Indonesia, khususnya terhadap sejarah perempuan Indonesia.

Kata Kunci: fakta historis, historical memory dan collective memory, kekerasan dan ketidakadilan gender, hegemoni maskulinitas, perempuan Indonesia

\begin{abstract}
Why Women Should Always Be: From the Sexual Restraint to the Hegemony of Masculinity in the Soekarno Film. Soekarno Film presented by Hanung Bramantyo is a description of historical facts which are related to Indonesian women and which are then commodified into texts and visual narrative films. The representation form of the commodification of historical facts of Indonesian women is showed in the visualization of gender inequality through the practices of sexual politics, sexual violence, and psychological violence until sexual restraint caused by the hegemony of Japanese colonialism through the practice of sexual slavery (jugun ianfu), and the attitude of Soekarno figure which appears to Inggit Ganarsih figure. The symbolic meanings of the narrative and visualization elements which are presented in the film of Soekarno are the strategy of culture and media politics to make the film as the medium of historical memory and collective memory for the Indonesian people to fight against the forgetting of a narrative description of the history of Indonesia, especially to the history of Indonesian women.
\end{abstract}

Keywords: historical facts, historical memory and collective memory, violence and inequality gender, hegemony of masculinity, Indonesian women 


\section{Pendahuluan}

Film sebagaimana karya sastra merupakan karya seni yang berangkat dari persoalan mimetis. Penciptaan film sebagai karya seni tidak dapat dihindarkan dari eksistensi fakta-fakta sosial, kebudayaan, sejarah, tradisi, ideologi maupun kehidupan psikologis masyarakat pada suatu zaman. Menurut Sumarno (1996:23) bahwa film yang baik adalah film yang mampu merepresentasikan kenyataan sosial pada zamannya. Film yang baik adalah arsip sosial yang menangkap jiwa zamannya (zeitgeist) saat itu (Imanjaya, 2006:30). Artinya, film dihadirkan oleh para sineas sebagai wujud dari representasi dan mozaik kehidupan masyarakat dalam wujud teks-teks atau narasi-narasi audiovisual yang dihadirkan kepada publik melalui bantuan seperangkat peralatan sinematik yang mencirikan zamannya. Pakar filmologi bersepakat bahwa esensi film dapat dikaji dengan lebih memadai pada tataran tekstual, bukan pada tataran sintaksis atau gramatika semata-mata (Budiman dkk, 2013). Pemikiran yang lain ditunjukkan Metz (1974:93); Andrew (1976:234); Budiman dkk (2013) yang mengemukakan bahwa sarana penyampai makna yang khas dalam film sebetulnya terletak dalam penataan sekuens-sekuens, bukan dalam shot atau scene karena film pada hakikatnya adalah teks naratif yang "menyampaikan cerita". Visualisasi teks-teks naratif adalah representasi pesan dan makna-makna simbolik yang harus dimaknai sebagai suatu sistem komunikasi yang bersifat massa karena film merupakan komodifikasi budaya massa dan populer.

Dalam konteks komunikasi massa, film merupakan produk yang memiliki fungsi-fungsi yang menjadi kekhasan dari perilaku komunikasi massa, sebagaimana yang dikemukakan oleh Jay Black dan Frederick C. Whitney (dalam Nurudin, 2014:64) antara lain: (1) to inform (menginformasikan), (2) to entertain (memberi hiburan), (3) to persuade (membujuk), dan (4) transmission of the culture (transmisi budaya). Hal ini dilatarbelakangi oleh realitas film yang memberikan informasi, memberi hiburan, membujuk, dan menjadi media transmisi budaya, meskipun film merupakan karya seni yang mengandung konsep dan fungsi-fungsi kemanusiaan, pendidikan, sosial, ekonomi, ideologi, kebudayaan, sejarah, lingkungan, dan politik pada zamannya sebagai komodifikasi content film. Salah satu tipe dari komodifikasi yang penting bagi komunikasi massa adalah komodifikasi isi. Komodifikasi isi menjadi pusat perhatian kajian ekonomi politik media dan komunikasi. Ketika pesan atau isi komunikasi diperlakukan sebagai komoditas, ekonomi politik cenderung memusatkan kajian pada konten (content) media (Ibrahim dan Akhmad, 2014:20).

Dalam perkembangan film di Indonesia, fakta historis seringkali dijadikan komodifikasi oleh sineas sebagai tema-tema content film, seperti film-film bergenre sejarah Indonesia di antaranya film Darah dan Doa (Usmar Ismail, 1950), Enam Jam di Jogja (Usmar Ismail, 1951), Pengkhianatan G 30 S/PKI (Arifin C Noer, 1982), Tjoet Nya' Dien (Eros Djarot, 1988), Gie (Riri Reza, 2005), Garuda di Dadaku (Ifa Isfansyah, 2009), Darah Garuda (Merah Putih II) (Yadi Sugandi dan Conor Alyyn, 2010), Sang Pencerah (Hanung Bramantyo, 2010), Soegija (Garin Nugroho, 2012), Habibie \& Ainun (Faozan Rizal, 2012), Sang Kiai (Rako Prijanto, 2013), Soekarno (Hanung Bramantyo, 2013), dan Tjokro Guru Bangsa (Garin Nugroho, 2015). Masyarakat Indonesia sebagai masyarakat pascakolonial, yang merujuk pada periode historis pascakemerdekaan, memiliki empirisme terhadap praktik-praktik kolonalisme fasisme. Menurut Purcell dalam Mariana (2015:18) fasisme secara konseptual, secara kerangka teoritis, adalah sebuah kondisi ideologi sayap kanan, ultranasionalisme, dan rasis dianut dan diterapkan. Fasisme apabila dianut oleh negara akan memunculkan sebuah rezim pemerintahan yang rasis, militeristik, diktator, dan berpartai tunggal. Praktik-praktik kolonialisme fasisme merupakan fakta historis yang terepresentasikan menjadi bagian dari catatan kritis praktik-praktik pengingkaran derajat kehormatan manusia sekaligus pelanggaran hak asasi manusia dan nihilisme terhadap nilai-nilai kemanusiaan. Fakta historis dari praktik kolonialisme fasisme di Indonesia ditunjukkan oleh representasi Pemerintahan Militer Jepang dalam kontestasi Perang Dunia II.

Konsep kunci dari karakteristik rezim fasis 
adalah "politik pemenjaraan" terhadap "musuh negara" (Mariana, 2015:24). Pada masa Jepang, siapa saja dapat dengan mudah dituding sebagai musuh negara, apabila menolak atau tidak mendukung kebijakan rezim fasis Jepang, seperti dalam kasus romusha dan jugun ianfu karena rezim fasis Jepang memosisikan kebijakan-kebijakannya sepenuhnya diperuntukkan bagi kepentingan perang. Politik kolonial Jepang dibangun berdasarkan sistem fasis yang militeristik. "Politik pemenjaraan" semasa rezim fasis Jepang berlangsung dalam dua bentuk. Pertama, "politik pemenjaraan" terhadap kaum kulit putih dan kaum intelektual, yaitu masyarakat kelas menengah. Kedua, "politik pemenjaraan" terhadap perempuan yang "dikumpulkan" di berbagai ianjo di seluruh negeri (Mariana, 2015:25).

Praktik-praktik kolonialisme fasisme Jepang terhadap perempuan Indonesia terlihat dalam beberapa film Indonesia, meskipun bukan menjadi content utama film yang secara khusus dihadirkan kepada publik sebagai representasi teks naratif film oleh sineas. Praktik kolonialisme fasisme Jepang terkadang menjadi momen-momen "pemanis" tertentu dalam kesatuan struktur naratif film, seperti adegan seks ketika perempuan Indonesia diperkosa atau saat harus menjadi jugun ianfu melayani hasrat seksual tentara fasis Jepang. Keadaan ini yaitu penderitaan yang dirasakan oleh perempuan Indonesia oleh rezim fasisme Jepang sangat merendahkan hak asasi dan harga diri bangsa Indonesia dengan menjadikan perempuan Indonesia sebagai budak seks tentara Jepang dan pemerintah Jepang menganggap hal itu bukan kejahatan perang selama mereka menjajah Indonesia. Tragisnya lagi bahwa pemerintahan Jepang hingga kini tidak bersedia meminta maaf sebagai wujud political will terkait tindakan kejahatan masa Perang Dunia II, termasuk soal perbudakan seks terhadap ratusan ribu perempuan dari sejumlah negara Asia (Kompas, 2 Mei 2015). Fakta sudah menunjukkan sangat jelas bahwa di tahun 2001 pengadilan internasional yang digelar di Den Haag, Belanda memutuskan Kaisar Hirohito sebagai penjahat perang karena menjadikan sekitar 20.000 perempuan di Asia sebagai budak seks (Kompas, 10 Desember 2001; Mardiana, 2015:73).

Dalam sebuah negara fasis, kedudukan perempuan dipandang hanya sebagai objek, bukan subjek. Konsep bahwa perempuan memiliki hak mandiri untuk menentukan apa yang diinginkannya tidak ada dalam negara fasis (Purcell dalam Mariana, 2015:18). Kedudukan perempuan sebagai objek adalah bentuk yang paling nyata dalam upaya sebuah rezim fasis melakukan penundukan atas suatu bangsa. Hal itu sebagaimana yang terjadi pada masa penjajahan Jepang, ketika Dai Nippon melakukan mobilisasi perempuan Indonesia sebagai bagian dari wujud penundukan wilayah dengan memasukkan beratus-ratus perempuan dalam ianjo-ianjo (Mariana, 2015: 18-19).

Tindakan praktik kekerasan seksual kepada perempuan Indonesia juga tidak sebatas pada masa kolonialisme fasisme Jepang. Secara konstruksi sosial dan budaya, perempuan Indonesia juga mengalami ketidakadilan secara gender yang diakibatkan oleh posisi perempuan yang terhegemoni. Konsekuensi logis dari persoalan konstruksi kebudayaan yang menempatkan inferior perempuan termanifestasikan ke dalam bentukbentuk diskriminatif seperti stereotipe, subordinasi, pelecehan seksual, double burden, kontrol terhadap seksual perempuan, dan kekerasan. Pembahasan mengenai persoalan perempuan menunjukkan satu konsep penting yang tidak boleh dilupakan adalah konsepsi gender karena masalah-masalah yang mengemuka merupakan bentuk dari berlangsungnya bias gender yang dipengaruhi oleh bentuk tatanan sosial dan budaya yang berlaku pada masyarakat yang menganut budaya patriarki. Menurut Fakih (1997:xii-xiii) sebagai teori, tugas utama analisis gender adalah memberi makna, konsepsi, asumsi, ideologi, dan praktik hubungan baru antara kaum laki-laki dan perempuan serta implikasinya terhadap kehidupan sosial yang lebih luas (sosial, ekonomi, politik, kultural).

Film Soekarno karya sutradara Hanung Bramantyo sarat dengan visualisasi dan representasi posisi perempuan dalam konteks relasi kuasa dengan laki-laki. Kondisi ini menunjukkan bagaimana perempuan dalam film direpresentasikan menjadi objek subaltern. Terma Subaltern digunakan dalam teori poskolonial untuk merujuk sekelompok orang-orang marjinal dan kelas rendah. Kata ini dirumuskan oleh Antonio Gramsci. Gramsci 
menegaskan bahwa kelompok ini memang ada karena adanya hegemoni. Secara sederhana definisi hegemoni adalah dominasi sekelompok orang terhadap kelompok lainnya, dengan atau tanpa paksaan (Kartika, 2011). Dalam semangat lebih dalam, kata Subaltern menjadi sering digunakan setelah seorang third-world-India-postcolonialfeminist yang menjadi Profesor Avalon di Columbia University Amerika Serikat, Gayatri Chakravorty Spivak, menulis essay "Can the Subaltern Speak?" (Soekirno, 2006). Posisi perempuan Indonesia sebagai subaltern, baik sebagai objek historiografi kolonialis maupun sebagai subjek pemberontakan, konstruksi ideologi gender tetap mempertahankan laki-laki sebagai pihak yang dominan (Spivak, 1993:83). Hal ini terlihat pada visualisasi praktik hegemonik tentara fasisme Jepang terhadap perempuan muda Indonesia dan perilaku serta sikap yang ditunjukkan oleh tokoh Soekarno terhadap istrinya, yaitu tokoh Inggit Ganarsih terkait dengan relasi kuasa dalam urusan domestik. Ketidakadilan gender senantiasa berwajah perempuan tatkala berhadapan dengan situasional politik hegemoni dan politik patriarki oleh laki-laki dengan orientasi pada kepatuhan dan ketundukan perempuan.

Film mampu menghadirkan dalam sebuah realitas teks-teks naratif yang terbungkus dalam adegan-adegan dan gambar visual sebagai bentuk simbolisme-simbolisme dari mimetisme yang hadir di tengah masyarakat, termasuk sebagai kritik atas perlakuan ketidakadilan pada zamannya. Baudrillard (dalam Hananta, 2013) mengasumsikan bahwa film sebagai alat untuk menghadirkan "realitas sosial" yang direpresentasikan sebagai realitas media. Realitas media yang dibangun oleh film merupakan hasil pemikiran para pembuat film, yang di dalam pengembangannya mengikuti tuntutan pasar. Film Soekarno yang disutradarai Hanung Bramantyo merupakan genre film biografi sejarah yang tengah mengalami euforia pasar, dengan keberhasilan beberapa film bergenre sejenis, seperti Sang Pencerah, Sang Kiai, Soegija, dan Habibie \& Ainun. Meskipun demikian, dalam film Soekarno didominasi masa-masa pembuangan di Bengkulu dan era pendudukan kolonialisme fasisme Jepang.

Interpretasi dan wujud apresiasi untuk memaknai dalam artikel ini dengan bahasan dalam ob- jek film Soekarno sekaligus memaknai imaji visualisasi dari Hanung Bramantyo sebagai sineas dengan menggunakan teori encoding (proses produksi teks) dan decoding (konsumsi teks) Stuart Hall. Suatu keadaan yang akan ditunjukkan adalah bagaimana film sebagai produksi makna dan penonton atau pengkaji sebagai pihak yang memaknai makna sehingga unsur subjektivitas terhadap kajian film ini sangat berperan penting untuk menghasilkan pemaknaan atas makna-makna simbolik yang terdapat dalam content film Soekarno. Fakta-fakta yang diperoleh dalam film sebagai teks-teks naratif yang dijadikan sebagai objek data untuk kemudian diapresiasi dan dianalisis dengan menggunakan teknik intepretatif. Analisis data dalam kajian ini merujuk pada metode kualitatif dan metode deskriptif dengan menggunakan analisis intepretatif, yakni peneliti melakukan tafsir terhadap temuan data dari sudut fungsi dan peran kaitannya dengan unsur lain. Metode kualitatif deskriptif ini menuntut seorang peneliti untuk mengungkapkan fakta-fakta yang tampak atau data dengan dengan cara memberikan deskripsi (Hikmat, 2011:101). Menurut Siswantoro (2010), metode deskriptif menuntut seorang peneliti untuk mengungkapkan fakta-fakta yang tampak atau data dengan cara memberikan deskripsi. Fakta atau data merupakan sumber informasi yang menjadi basis analisis.

\section{“Pemenjaraan Seksual”: Film sebagai Historical Memory dan Collective Memory}

Menurut Ayawaila (2008:45), "Ada tiga hal yang perlu diperhatikan dalam menilik dokumenter sejarah, yaitu periode (waktu peristiwa sejarah), tempat (lokasi peristiwa sejarah), dan pelaku sejarah.” Artinya, film bertema sejarah tidak semata-mata merepresentasikan peristiwa dan waktu, melainkan juga merepresentasikan gambaran-gambaran pelaku atau tokoh sejarah yang kemudian divisualisasikan dalam wujud film sebagai teks historical memory (ingatan sejarah). Hal ini mengartikan bahwa film-film dengan genre sejarah dalam perspektif historis dapat difungsikan sebagai historical memory (ingatan sejarah) dan collective memory (ingatan kolektif) bagi perempuan Indonesia, terutama dari generasi 
muda yang sedang mengalami gejala sikap ahistoris agar tidak melupakan tragedi kemanusiaan yang dialami oleh kaum perempuan Indonesia semasa dalam kolonialisme fasisme Jepang.

Menurut Sobur (2004:127), film selalu merekam realitas yang tumbuh dan berkembang dalam masyarakat dan kemudian memproyeksikannya ke atas layar. Film sebagai media massa menyajikan cerita dan peristiwa terkait dengan hal jangkauan, realisme, pengaruh emosional, dan popularitas yang hebat. Film juga memiliki kelebihan dalam segi kemampuannya menjangkau sekian banyak orang dalam waktu singkat dan mampu memanipulasi kenyataan tanpa kehilangan kredibilitas (Hananta, 2013). Pada titik inilah historical memory dan collective memory menjadi penting terkait dengan realitas tentang kehadiran praktik pemenjaraan dan perbudakan seksual perempuan Indonesia dalam film Soekarno untuk memengaruhi emosional publik agar senantiasa menolak dan melawan lupa atas tragedi kemanusiaan dan sejarah.

Suatu upaya yang dilakukan terkait dengan historical memory dan collective memory terkait dengan jugun ianfu antara lain dengan menerbitkan buku-buku yang mengungkapkan fakta-fakta historis para jugun ianfu, seperti karya Pramoedya Ananta Toer (Perawan Remaja dalam Cengkraman Militer), Eka Hidra dan Koichi Kimura (Momoye Mereka Memanggilku), George Hicks (Comfort Women), Anna Mariana (Perbudakan Seksual). Dalam hal lainnya juga dengan mengkaji dan mengkritisi produk-produk budaya popular, salah satunya adalah film, seperti film dokumenter Indonesian Comfort Women: A Video Testimony, produksi Offstream tahun 2000 maupun beberapa film bergenre biografi sejarah seperti Film Soegija, Sang Kiai, dan Soekarno juga menampilkan bagian cerita sejarah para perempuan Indonesia menjadi kebiadaban tentara fasisme Jepang yang dipresentasikan dalam beberapa scene atau adegan.

Film merupakan media yang paling efektif terkait dengan internalisasi indoktrinasi, penanaman ideologi, propaganda, dan stimulasi ingatan publik melalui representasi teks-teks audiovisual dari sebuah realitas kehidupan. Sineas dengan sendirinya memiliki ideologi dan pesanpesan moral yang ingin disampaikan kepada publik. Film merupakan media paling efektif untuk menanamkan kepada publik fakta-fakta historis tentang ketidakadilan relasi kuasa patriarki yang dilakukan oleh negara ataupun suatu entitas konstruksi budaya komunal seperti pada saat Indonesia dalam kekuasaan kolonialisme fasisme Jepang, sebagai bagian dari historical memory dan collective memory pada diri kaum perempuan.

Salah satu film Indonesia yang ber-setting masa kolonialisme fasisme Jepang adalah film Soekarno (Hanung Bramantyo, 2013). Dalam film ini digambarkan bagaimana tokoh Soekarno dipaksa oleh Pemerintah Militer Jepang untuk "menyediakan” perempuan-perempuan muda sebagai jugun ianfu dan romusha sebagai konsekuensi mendukung peperangan tentara Jepang di bawah jargon 3A (Nippon Pelindung Asia, Nippon Pemimpin Asia, dan Nippon Cahaya Asia). Tokoh Soekarno memilih berkolaborasi dengan Pemerintahan Militer Jepang semata-mata sebagai strategi diplomasi untuk meraih kemerdekaan dan menghindari pertumpahan darah, meskipun konsekuensi logisnya tokoh Soekarno distigma sebagai pengkhianat oleh beberapa pihak dari kalangan gerakan perjuangan kemerdekaan Indonesia, seperti tokoh Sutan Sjahrir dan beberapa kelompok pemuda anti-Jepang, termasuk kalangan santri yang tidak setuju dengan langkah tokoh Soekarno mendatangkan pelacurpelacur di daerah mereka untuk melayani hasrat seksual tentara Jepang. Prostitusi yang dikelola oleh militer Jepang yang fasis. Pada saat Soekarno melihat para pelacur-pelacur yang didatangkan menjadi budak seks tentara Jepang maka Soekarno pun merasakan kepedihan dalam hati karena tetap menganggap bahwa para pelacur-pelacur itu adalah perempuan Indonesia sebagai korban perbudakan seksual tentara Jepang.

Data dalam film tersebut menunjukkan bagaimana para perempuan Indonesia mengalami perlakukan kekerasan seksual dengan menjadikan mereka sebagai budak-budak seksual oleh negara dalam hal ini pemerintahan fasisme Jepang. Perempuan-perempuan Indonesia yang diculik secara paksa kemudian dipenjarakan secara seksual. Para perempuan Indonesia mengalami hegemoni dan ketidakdilan secara politik seksual dengan memosisikan para perempuan dalam pemenjaraan 
seksual. Keadaan ini menunjukkan bagaimana perempuan Indonesia mengalami pelecehan seksual, kekerasan fisik, dan kekerasan psikis. Menurut Francois Chirpaz dalam Haryatmoko (2007:120), kekerasan adalah kekuatan yang sedemikian rupa dan tanpa aturan yang memukul dan melukai baik jiwa maupun badan, kekerasan juga mematikan entah dengan memisahkan orang dari kehidupannya atau dengan menghancurkan dasar kehidupannya. Suatu kenyataan yang menunjukkan bagaimana perempuan Indonesia mengalami kekerasan karena adanya ketidaksetaraan kekuatan yang diciptakan oleh negara, dalam hal ini pemerintahan kolonialisme fasisme Jepang. Dalam konteks teori analisis gender bahwa kolonialisme fasisme Jepang telah melakukan kejahatan yang bisa
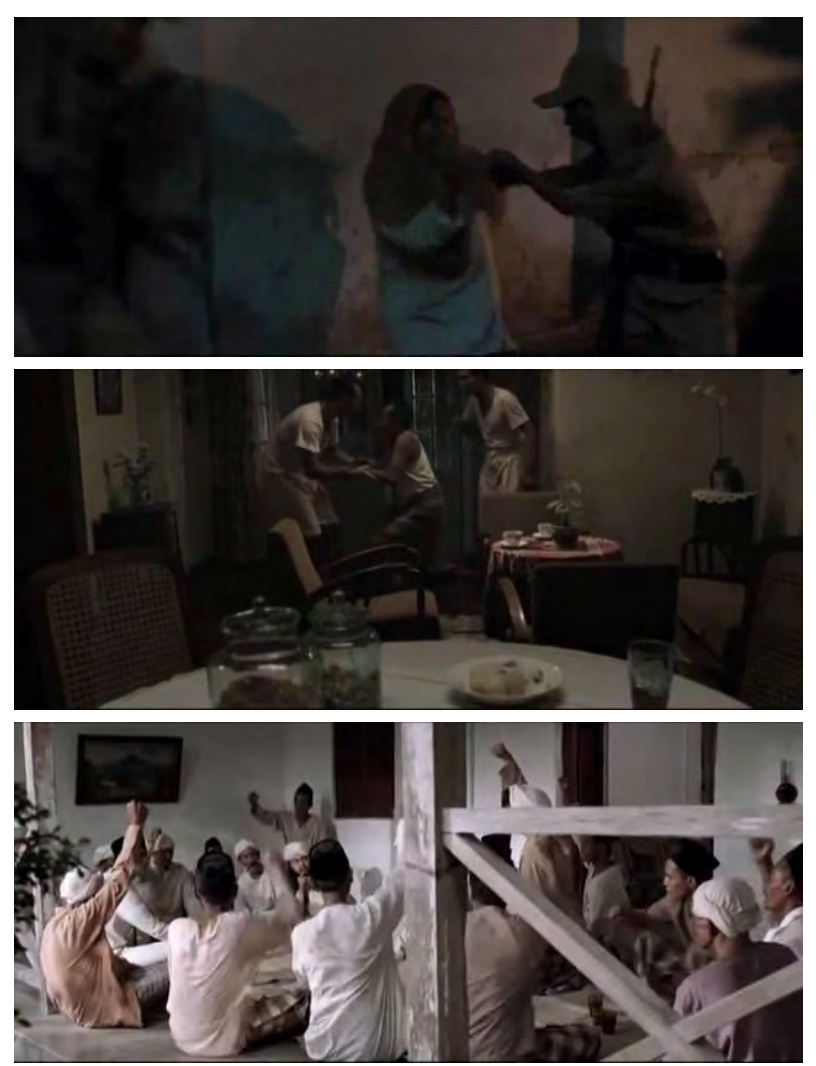

dikategorikan kekerasan gender. Pertama, bentuk pemerkosaan terhadap perempuan. Perkosaan terjadi jika seseorang melakukan paksaan untuk mendapatkan pelayanan seksual tanpa kerelaan yang bersangkutan. Ketidakrelaan ini seringkali tidak bisa terekspresikan disebabkan oleh pelbagai faktor, misalnya ketakutan, malu, keterpaksaan baik ekonomi, sosial maupun kultural, tidak ada pilihan lain. Kedua, kekerasan dalam bentuk pelacuran (prostitution). Pelacuran merupakan bentuk kekerasan terhadap perempuan yang diselenggarakan oleh suatu mekanisme ekonomi yang merugikan kaum perempuan. Ketiga, tindakan kejahatan berupa pelecehan seksual (sexual and emotional harassment) terhadap perempuan (Fakih, 2007: 18-20).
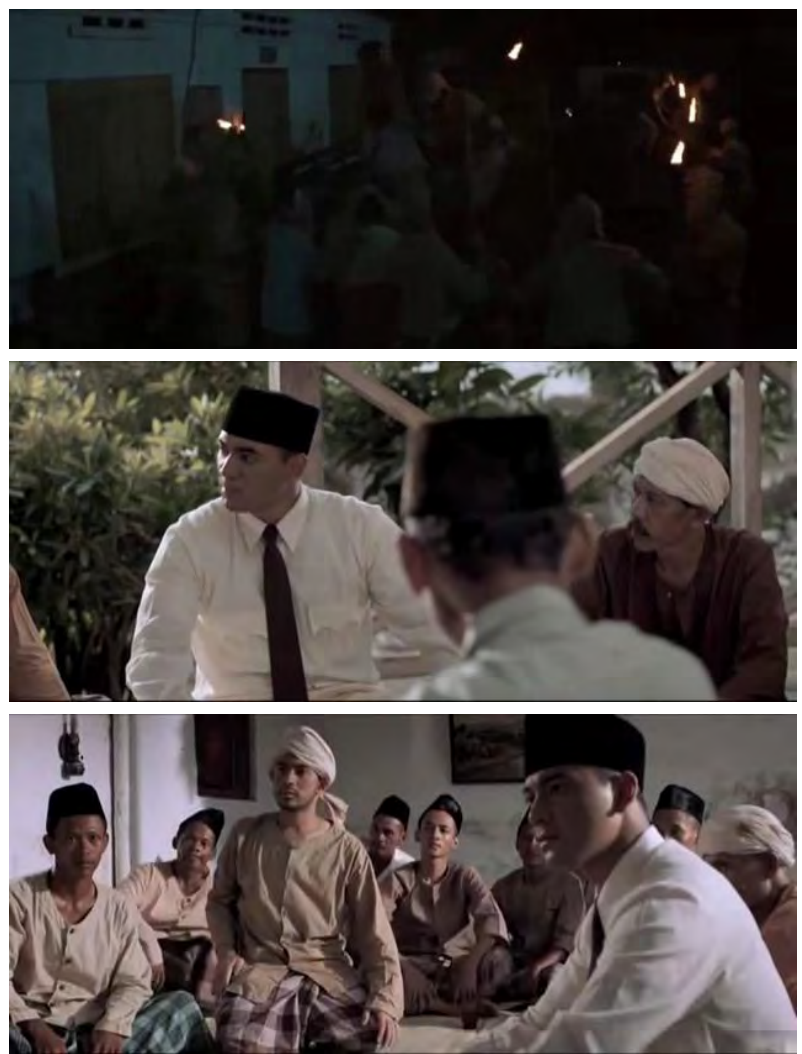

Tentara fasisme Jepang menculik para anak-anak gadis untuk dijadikan budak seks. Seorang bapak yang anak gadisnya diculik oleh tentara Jepang menemui Soekarno dan melaporkan tindakan tentara Jepang tersebut. Soekarno kemudian menemui para kyai dan santri untuk membahas persoalan tindakan tentara fasisme Jepang yang menculik anak-anak gadis untuk mendatangkan para pelacur agar para anak gadis-anak gadis Indonesia tidak menjadi korban perbudakan seksual tentara Jepang.

Kyai : Tidak bisa haram hukumnya.

Soekarno : : [MS] Bagaimana kalau saya mendatangkan pelacur di sini.

Para Santri : : [serentak] Tidak bisa....tidak bisa....tidak bisa

Santri $1 \quad$ : Sama saja Bung Karno. Sama saja kita membiarkan perzinahan itu ada.

Para Santri : [serempak] ya.....yaa....ayaaa.

Soekarno $\quad:$ [MS] kalau tidak. Tentara nippon akan mengambil anak-anak gadis kalian.

Para Santri : : [serentak] Kita akan angkat senjata.....ya...ya...kita angkat senjata

Santri 2 : Tenang..tenang..! Senjata apa pun tidak akan mampu mengalahkan mereka. Nippon akan membantai dengan Soekarno : [mengangguk] mudah perempuan, anak-anak kita, orang tua akan habis dibantai. Bukan begitu Bung Karno! 

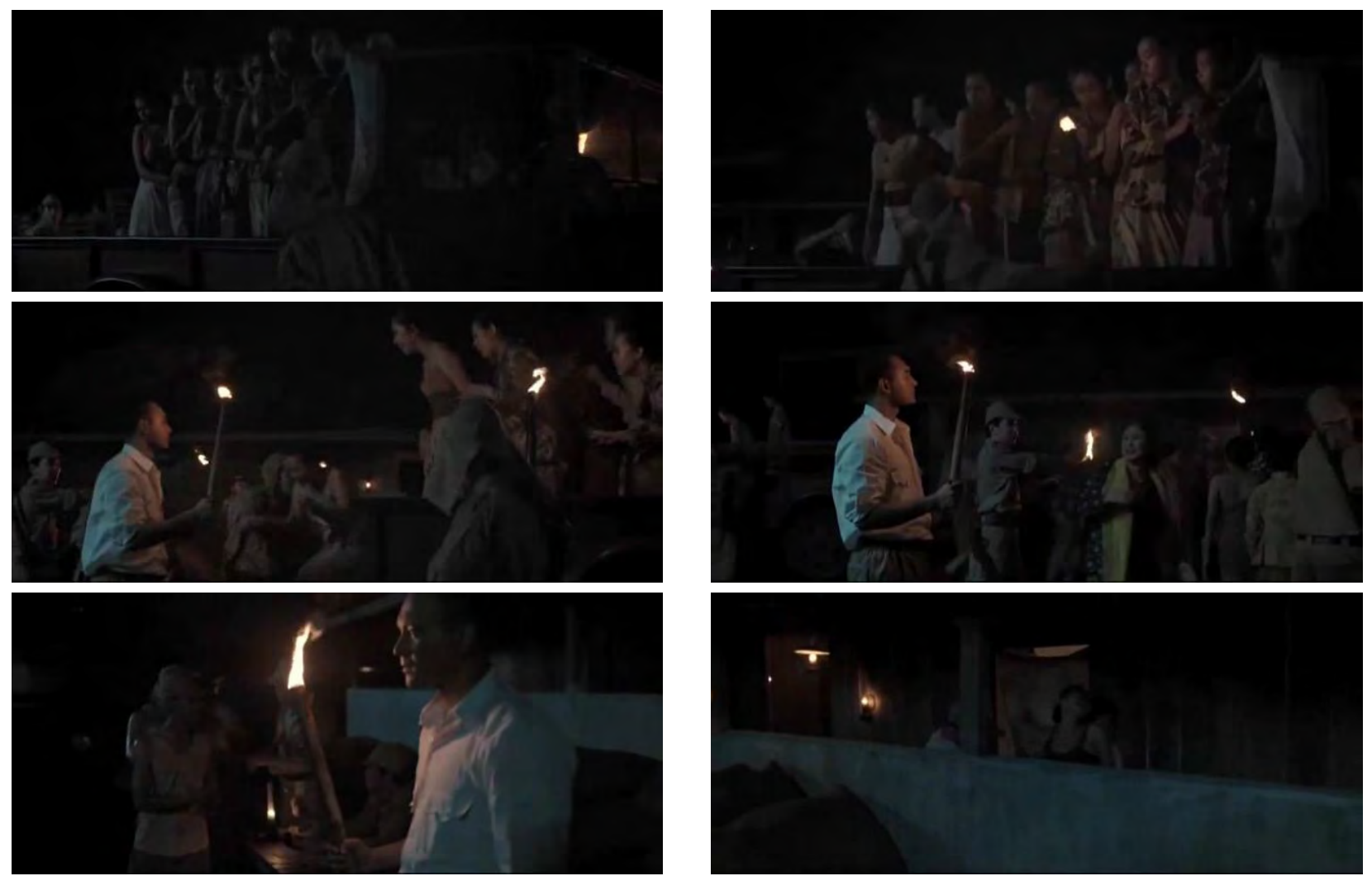

Soekarno pun kemudian mendatangkan pelacur-pelacur ke markas tentara fasisme Jepang dengan bantuan Cuecue yang telah dikenalnya. Namun begitu, hati Soekarno sangat sedih melihat perlakuan para tentara fasis Jepang. (Soekarno, 2013, Part 1, 00:50:29 - 00:52:35)

Tokoh Soekarno harus berkompromi dengan pihak tentara fasisme Jepang dengan melakukan "politik seksual" agar tidak terjadi penculikanpenculikan dan pengambilan-pengambilan paksa perempuan muda Indonesia, meskipun pada awalnya memperoleh tentangan dari para santri-santri yang tidak ingin wilayah mereka menjadi pusat prostitusi atau perzinaan. Langkah yang terpaksa dilakukan oleh tokoh Soekarno dengan mendatangkan para pelacur untuk melayani hasrat seksual tentara Jepang. Para pelacur pun pada akhir-nya juga terjebak dalam perbudakan seksual yang berkepanjangan. Kondisi ini ditunjukkan bahwa satu pelacur dalam semalam harus memenuhi hasrat seksual beberapa puluh tentara Jepang yang liar dan tidak menghargai kehormatan perempuan tersebut. Tokoh Soekarno secara tidak langsung juga terjebak dalam praktik-praktik kekerasan gender meskipun untuk alasan yang sangat mulia yaitu menghindarkan perempuan-perempuan Indonesia mengalami penculikan dan pengambilan paksa oleh tentara fasisme Jepang. Dilema moralitas dan konsekuensi dari perjuangan melawan hegemonik kolonialisme ditunjukkan dalam kenyataan ini.
Tindakan pelecehan seksual dan perbudakan seksual dari praktik politik seksual pemerintahan militer Jepang yang fasis dengan memanfaatkan popularitas dan kepercayaan publik kepada Soekarno untuk melegalkan praktik jugun ianfu atas permintaan perwira militer Jepang Shakaguci dalam film Soekarno dapat diposisikan sebagai narasi historis yang senantiasa tidak boleh dilupakan oleh bangsa Indonesia. Tindakan perbudakan seksual yang dialami oleh perempuan Indonesia harus menjadi historical memory dan collective memory bagi seluruh bangsa Indonesia bahwa tindakan kolonialisme senantiasa menyebabkan perempuan sebagai pihak yang lemah akan mengalami ketidakadilan gender termasuk kekerasan seksual dan hegemonik pada diri perempuan Indonesia, melalui manifestasi penguasaan atas tubuh perempuan Indonesia. Kondisi yang tidak boleh terulang karena jelas merampas hak asasi manusia. Segala keadaan yang dialami oleh perempuan Indonesia dalam film Soekarno menjadi suatu nukilan fakta sejarah yang harus selalu ditampilkan tidak dalam rangka membuka luka lama bagi para perempuan korban jugun ianfu atau perbudakan 
seksual, melainkan sebagai historical memory dan collective memory yang berfungsi sebagai peringatan dan kekuatan perjuangan bagi perempuan dan seluruh bangsa Indonesia untuk memerangi segala tindakan kolonialisme dan penghegemonian perempuan melalui eksploitasi politik seksual. Perempuan jangan lagi menjadi korban dari ketidakadilan yang dilakukan golongan patriarkar yang memosisikan perempuan semata-mata sebagai objek seksual.

Pendekatan "politik seksual" akan menempatkan posisi perempuan berhadap-hadapan dengan kekuasaan laki-laki (Koentowijoyo, 2003:118-119; Mariana, 2015:20). Hal ini berarti bahwa dalam konteks relasi kuasa menunjukkan bagaimana pada masa kolonialisme fasisme Jepang perempuan Indonesia mengalami kekerasan seksual yang dilakukan oleh negara. Ketertundukan merupakan simbol dari upaya negara untuk "menertibkan" para perempuan yang pada akhirnya hanyalah bertujuan untuk menempatkan perempuan dalam posisi yang rentan terhadap perilaku kekerasan (Mariana, 2015:21).

\section{Hegemoni Maskulinitas: Antara Dua Perempuan}

Sistem masyarakat yang ditandai dengan polapola interaksi, struktur sosial, membicarakan dan membedakan fungsi serta peran masing-masing anggota yang dipengaruhi oleh dominasi suatu kebudayaan kekuasaan seringkali terjadi dan berakibat kepada terjadinya persoalan diskriminasi dan ketidakadilan. Persoalan diskriminasi dan ketidakadilan pada akhirnya menciptakan hierarkis superior dan inferior. Keadaan ini ditunjang oleh eksistensi nilai budaya yang hegemonis, misalnya budaya patriarki di mana kekuasaan laki-laki mampu menghegemoni dan mensubordinasikan kaum perempuan (Kartika, 2010). Penindasan perempuan berakar pada kaum laki-laki. Penguasaan fisik perempuan oleh lakilaki itu adalah bentuk dasar penindasan (Jaggar dalam Fakih, 2007:102). Patriarki dalam hal ini merupakan sistem hirarki seksual di mana laki-laki memiliki kekuasaan superior dan privilege ekonomi (Fakih, 2007:102-103).
Relasi kuasa antara laki-laki dan perempuan dalam konteks hegemoni maskulinitas yang ditopang oleh pengakuan budaya patriarki telah memosisikan terjadinya ketidakadilan bagi perempuan. Hal ini disebabkan ada kaitan yang erat antara perbedaan gender (gender differences) dan ketidakadilan gender (gender inequalities) dengan struktur ketidakadilan masyarakat secara lebih luas (Fakih, 2007:3). Salah satu bentuk aktualisasi dari ketidak-adilan gender pada perempuan adalah tindakan kekerasan. Tindakan kekerasan yang terkait dengan perbedaan jenis kelamin dikenal dengan istilah gender based violence (La Pona dkk., 2002:9). Menurut La Pona dkk. (2002:7), kekerasan terhadap perempuan adalah tindakan seorang laki-laki atau sejumlah lakilaki dengan menggerakkan kekuat-an tertentu sehingga menimbulkan kerugian atau penderitaan secara fisik, seksual, atau psikologis pada seorang perempuan atau sekelompok perempuan, termasuk tindakan yang bersifat memaksa, mengancam, dan atau berbuat sewenang-wenang, baik yang terjadi dalam kehidupan bermasyarakat maupun dalam kehidupan pribadi di masyarakat domestik dan publik.

Kekerasan terhadap perempuan dapat dibedakan menjadi dua bentuk, yakni kekerasan seksual dan nonseksual (Dzuhayatin dan Yuarsi, 2002:6). Perbedaan yang terlihat di antara kedua jenis kekerasan tersebut adalah ada atau tidaknya unsur kehendak seksual. Terdapatnya unsur kehendak seksual menunjukkan bahwa kekerasan tersebut dapat dikategorikan sebagai kekerasan seksual maka sebaliknya apabila unsur tersebut tidak dominan, hal ini menunjukkan bahwa kekerasan tersebut dimasukkan dalam kategori nonseksual.

Laki-laki penguasa selain melakukan kekerasan seksual juga mempunyai anggapan bahwa perempuan merupakan objek kekerasan psikis dan fisik. Kekerasan dalam artikel ini mengacu pada arti kekerasan yang disusun dalam konferensi ke-4 tentang perempuan di Beijing tahun 1995: Aksi kekerasan yang didasarkan pada gender yang berakibat atau mungkin mengakibatkan kerusakan fisik, seksual, atau psikologis atau penderitaan perempuan termasuk ancaman-ancaman dari aksiaksi semacam itu, pemaksaan atau perampasan 
kemerdekaan dengan sewenang-wenang yang terjadi baik dalam kehidupan publik maupun pribadi (United Nation dalam Djannah, dkk dalam Kartika, 2010).

Kekerasan psikis merupakan salah satu manifestasi dari bentuk kekerasan kepada perempuan. Kekerasan (violence) adalah serangan atau invasi (assault) terhadap fisik maupun integritas mental psikologis seseorang (Fakih, 1997:17). Kekerasan
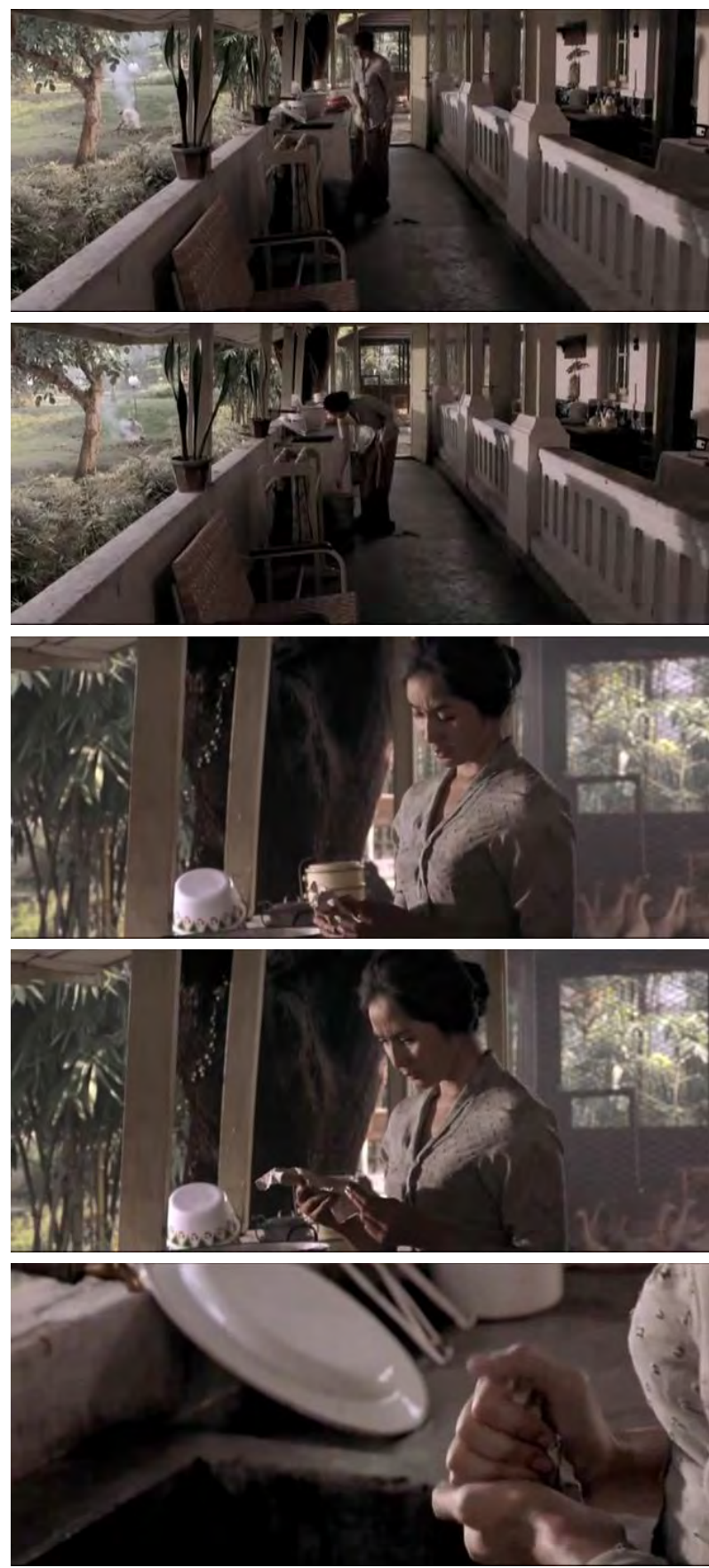

psikis memang tidak meninggalkan bekas sebagaimana kekerasan fisik, tetapi berkaitan dengan harga diri perempuan. Pelanggaran komitmen, penyelewenangan, teror mental dan teror pembunuhan, serta pengucapan kata-kata yang tidak menyenangkan merupakan kekerasan psikis yang dialami oleh tokoh perempuan (Sofia, 2009:42).

Kekerasan psikis dialami oleh tokoh Inggit Ganarsih tatkala mengetahui bahwa tokoh Soe-
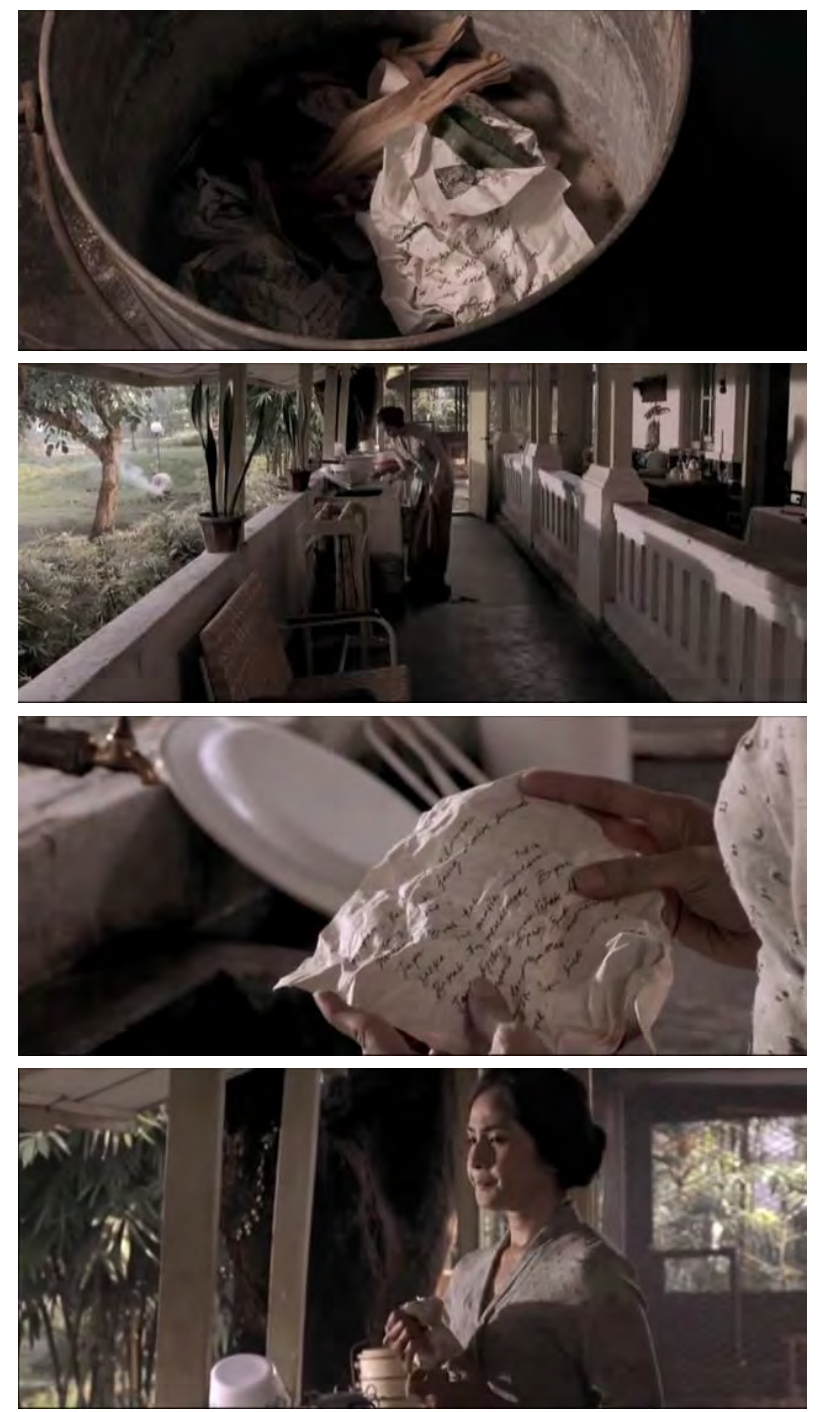

[MS Inggit sedang membaca surat dari Fatmawati]

[VO suara Fatmawati] “....tapi Bapak tahu, Fat masih mencintai Bapak. Fat menunggu Bapak. Tapi jika Bapak tidak bisa memenuhi janji Bapak. Fat terpaksa harus menerima lamaran. Semoga bapak bisa mengerti. Fatma” (Soekarno, 2013, Part 2, 00:00:05-00:01;16) 
karno menjalin hubungan percintaan dengan tokoh Fatmawati. Hal ini diketahui oleh tokoh Inggit Ganarsih ketika sedang membersihkan rumah di Pegangsaan Timur. Inggit Ganarsih menemukan sepucuk surat yang dibuang di tempat sampah. Isi surat menyiratkan ketetapan hati tokoh Fatmawati menunggu tokoh Soekarno menepati janji untuk memperistrinya karena pada saat yang bersamaan Fatmawati menerima sebuah pinangan dari orang lain. Soekarno apabila tidak bisa memenuhi janjinya maka Fatmawati akan menerima lamaran dari orang lain tersebut. Pada saat membaca isi surat
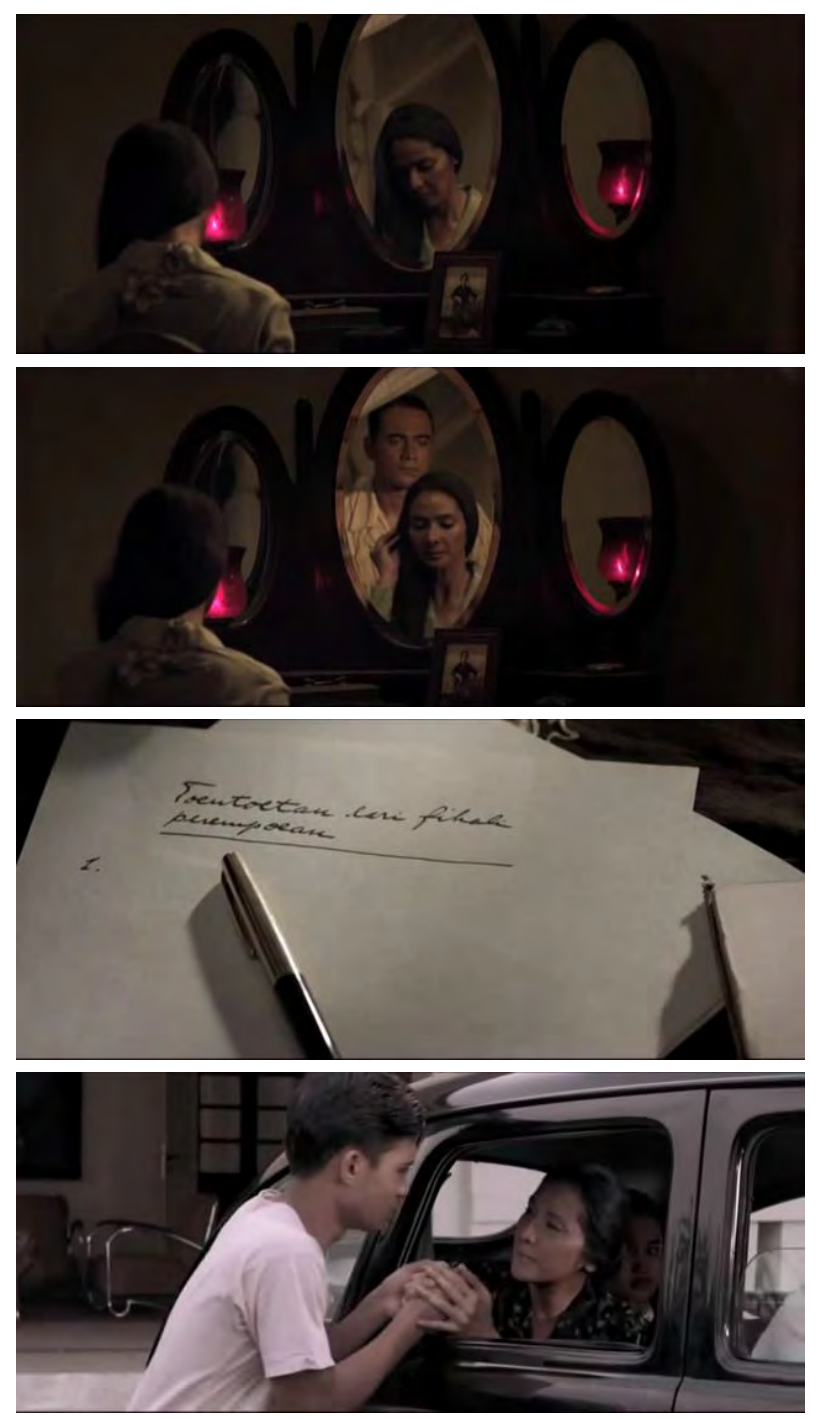

Soekarno

Inggit Ganarsih

Soekarno

Inggit Ganarsih

: Aku tidak ingin menceraikanmu, Git cinta. tersebut tergambar kepedihan dari raut wajah tokoh Inggit Ganarsih, sambil tangannya meremasremas surat tersebut dan dengan wajah menahan amarah bercampur dengan kekecewaan. Di bawah ini merupakan gambaran dari isi surat tokoh Fatmawati kepada tokoh Soekarno yang ditemukan dan dibaca oleh tokoh Inggit Ganarsih.

Dalam film Soekarno, kekerasan psikis dialami oleh tokoh Inggit Ganarsih, ketika tokoh Soekarno memutuskan ingin menikahi bekas muridnya, tokoh Fatmawati. Gadis yang dikenalnya selama menjadi guru Muhammadiyah di Bengkulu. Inggit
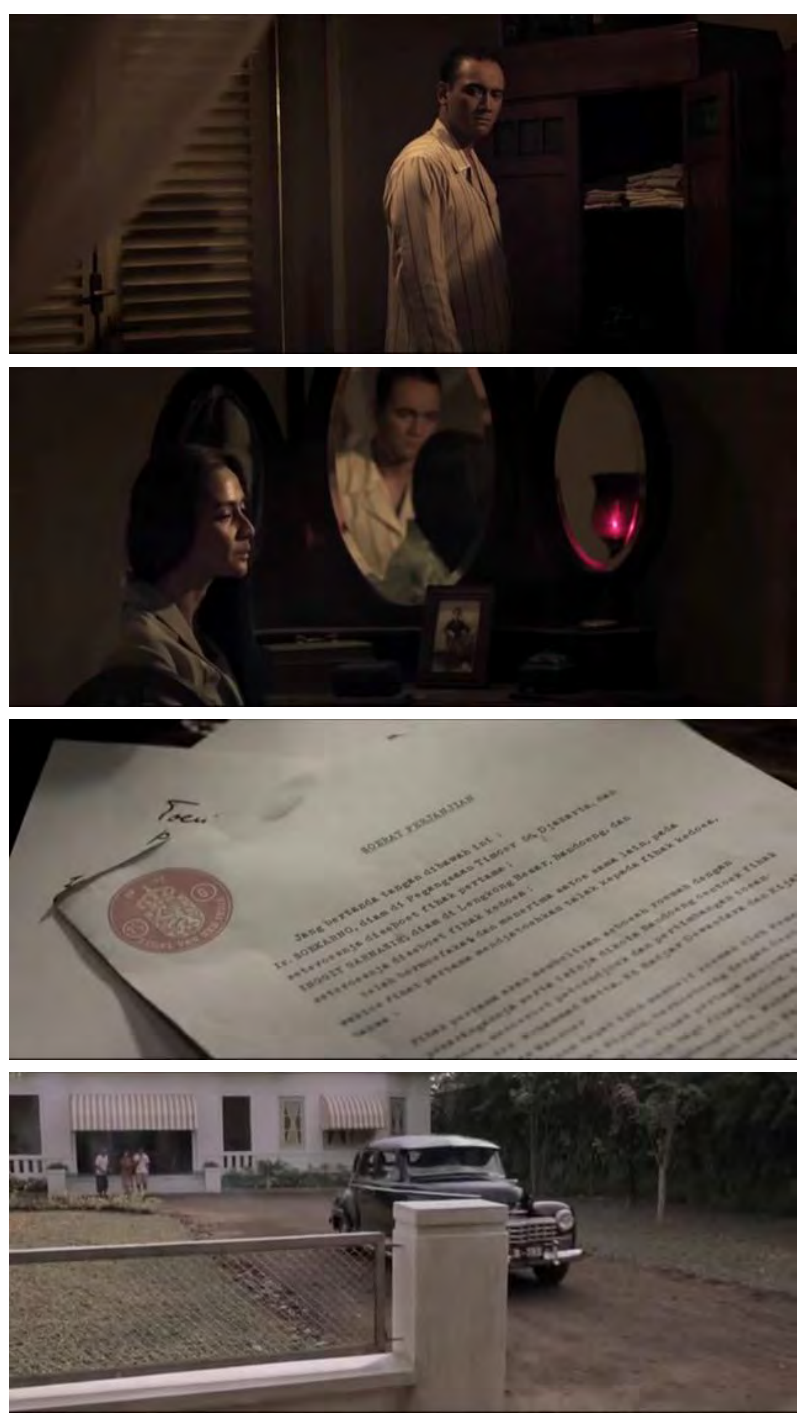

: [MS sedang menyuri rambut di depan cermin rias] Inggit tidak mau dimadu. Keadaan ini sudah lama Inggit bayangkan. Bahkan sejak kamu mengambil aku dari Kang Sanusi. Menikahi kamu tidak cukup hanya dengan 
Ganarsih merasa sakit hati ketika tokoh Soekarno dengan terbuka menyatakan keinginan untuk menikah lagi tanpa mempertimbangkan perasaan tokoh Inggit yang masih berstatus sebagai istri sahnya. Inggit Ganarsih pada akhirnya menerima dengan ikhlas sikap dan keputusan tokoh Soekarno. Inggit Ganarsih berketetapan untuk tidak mau dimadu. Tokoh Inggit Ganarsih memiliki jiwa besar dalam menghadapi sikap tokoh Soekarno yang ingin menduakan dirinya.

Tokoh Inggit Ganarsih menunjukkan bahwa sudah cukup bagi dirinya menemani dan mendukung tokoh Soekarno dalam meraih mimpi dan cita-citanya meraih kemerdekaan, meskipun pada akhirnya Inggit Ganarsih harus menderita. Ketulusan dan kesetiaan dirinya berbalas dengan pengkhianatan terhadap komitmen keduanya untuk mencintai sebagai suami istri. Pengorbanan harta benda, kesetiaan, ketulusan dalam melayani tokoh Soekarno sebagai suaminya tidak menggugah atau menggerakkan hati tokoh Soekarno untuk tidak menikahi wanita lain. Tokoh Soekarno dalam segala hal yang dilakukannya merupakan wujud dari pelanggaran dan penyelewengan komitmen dirinya kepada sang istri dalam berumah tangga. Tokoh Inggit Ganarsih pada akhirnya memutuskan untuk meninggalkan tokoh Soekarno daripada hidup dan tinggal bersama dalam satu rumah dengan tokoh Fatmawati.

Tokoh Soekarno pun kemudian memutuskan menceraikan tokoh Inggit Ganarsih. Inggit Ganarsih karena sudah diceraikan oleh tokoh Soekarno maka tokoh Inggit pun memutuskan untuk meninggalkan rumah Pegangsaan Timur. Saat tokoh Inggit Ganarsih sedang mengemasi pakaiannya, tokoh Soekarno pun mengutarakan keinginannya untuk mengantar tokoh Inggit Ganarsih. Tokoh Inggit Ganarsih pada awalnya menolak hingga akhirnya bersedia diantar oleh tokoh Soekarno dengan mobilnya.

Hal yang dilakukan oleh tokoh Inggit Ganarsih dengan tidak bisa menerima istri kedua merupakan suatu prinsip yang memang harus dipegang teguh oleh perempuan, sebab bagaimana pun yang menjadi korban tetap perempuan. Inggit Ganarsih meminta kepada tokoh Soekarno untuk menghormati prinsipnya. Sikap tokoh Inggit
Ganarsih merupakan sikap tegas yang memang harus dimiliki oleh perempuan untuk melawan ketidakadilan secara gender kepada dirinya. Kerelaan dirinya untuk meminta cerai jelas merupakan perlawanan pada diri tokoh Soekarno, wujud dari pemberontakan dari sistem patriarki yang melegalkan bahwa perempuan berada subordinasi dari laki-laki. Relasi kuasa yang selama ini memosisikan perempuan sebagai pihak yang terkalahkan.

Tokoh Inggit Ganarsih apabila bersedia di madu dengan menjadikan tokoh Fatmawati sebagai istri keduanya, secara tidak langsung tokoh Inggit Ganarsih melanggengkan dominasi dan subordinasi laki-laki terhadap perempuan. Oleh karena itu, langkah tokoh Inggit Ganarsih meminta cerai kepada tokoh Soekarno merupakan suatu bentuk kritik terhadap sistem konstruksi budaya patriarki bahwa perempuan pun berani secara rasional mengambil risiko dengan hidup mandiri tanpa bergantung kepada laki-laki atau suami. Sebuah dekonstruksi makna dari kemapanan budaya yang secara stereotipe memosisikan perempuan sebagai pribadi yang emosional dan irasional. Keberanian tokoh Inggit Ganarsih meminta cerai membuktikan bahwa dirinya memiliki rasionalitas dalam mengambil keputusan, termasuk tersirat suatu makna simbolik bagaimana tokoh Inggit Ganarsih memiliki rasa simpati dan empati kepada tokoh Fatmawati agar lebih memiliki kehormatan dengan menjadi satu-satunya istri dari tokoh Soekarno yang sah. Tokoh Inggit Ganarsih tidak ingin menjadi benalu bagi kehidupan keluarga baru Soekarno-Fatmawati. Soekarno dan Fatmawati diharapkan dapat hidup bahagia tanpa harus memikirkan persoalan Inggit Ganarsih sebab Inggit Ganarsih sudah tidak menjadi istri dari tokoh Soekarno.

Soekarno setelah menceraikan tokoh Inggit Ganarsih dalam film Soekarno, kemudian mengirimkan telegram kepada tokoh Fatmawati di Bengkulu. Isi telegram menyatakan bahwa tokoh Soekarno telah menikahi tokoh Fatmawati dengan perwakilan karena tokoh Soekarno tidak bisa datang ke Bengkulu. Soekarno mengajak tokoh Fatmawati bersama keluarganya untuk ke Jakarta pada tanggal 1 Juni 1943. 

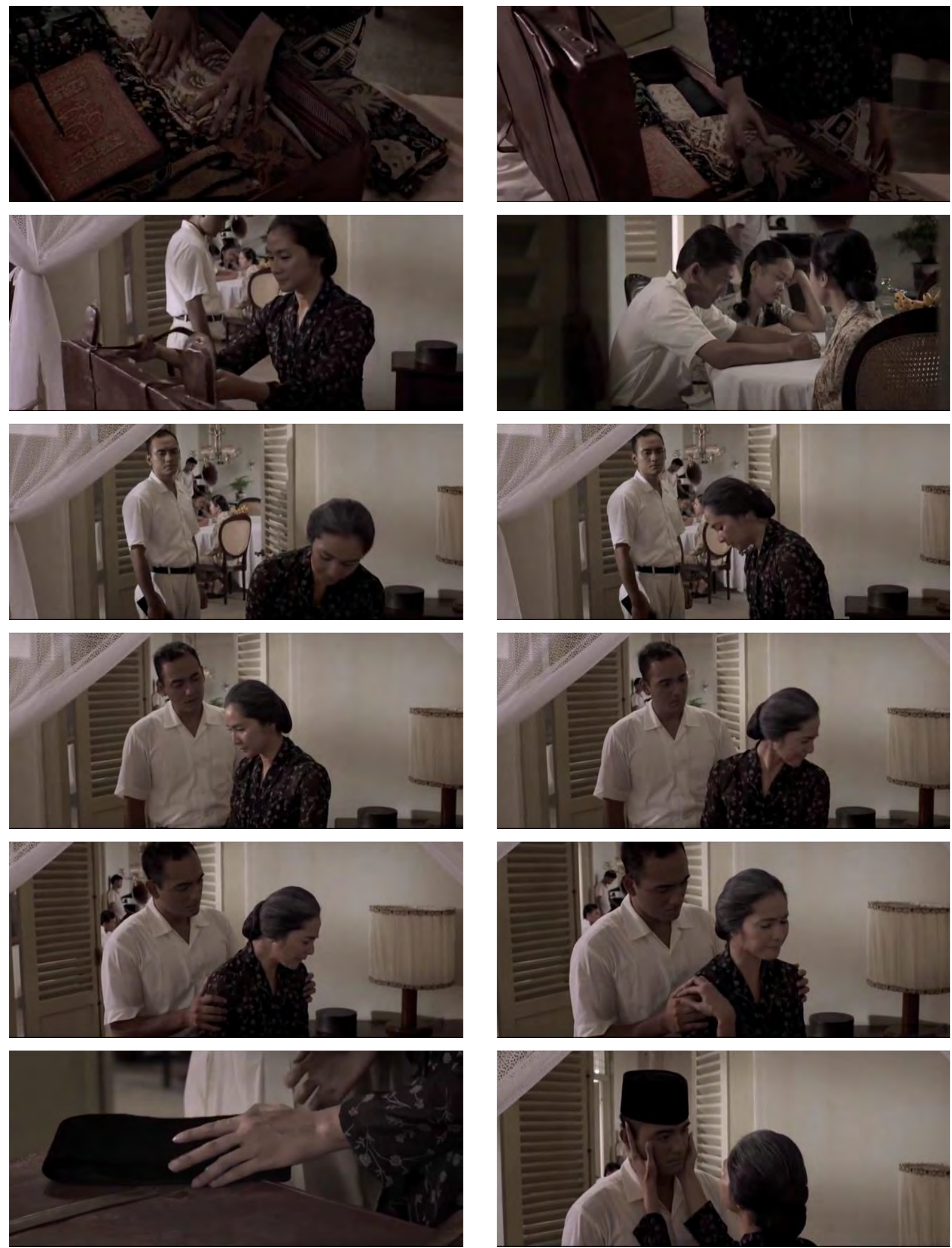

Inggit Ganarsih sedang memberesi pakaiannya dalam kopor. Anak-anak angkat Inggit Ganarsih dan Soekarno terlihat sedih dan muram di meja ruang tengah. Soekarno menemani Inggit Ganarsih dan mengutarakan keinginannya untuk mengantar Inggit Ganarsih ke tempat yang akan ditujunya sekeluar dari rumah Pegangsaan Timur.

Soekarno

Inggit Ganarsih
: [MS Soekarno dan Inggit Ganarsih yang sedang menata pakaian di dalam kopor] Dari sini kamu pulang ke mana?

: Ke rumah Haji Andar di Lengkong Besar. Kenalan baik waktu di Bandung. 
Soekarno

: Jalan kuantar

Inggit Ganarsih

: Nggak usah

Soekarno

: Ijinkan aku, melakukan sesuatu untuk terakhir kalinya

Inggit Ganarsih menangis membelakangi Soekarno. Soekarno mendatangi Inggit Ganarsih dan memegang bahu Inggit Ganarsih. Lantas Inggit Ganarsih mengambil peci Soekarno dan memasangkan di kepalanya serta menepuk dadanya. Lalu meninggalkan Soekarno. Inggit Ganarsih berangkat meninggalkan rumah Pegangsaan Timur dengan mobil. (Soekarno, 2013, Part 2, 00:04:49-00:06:51)
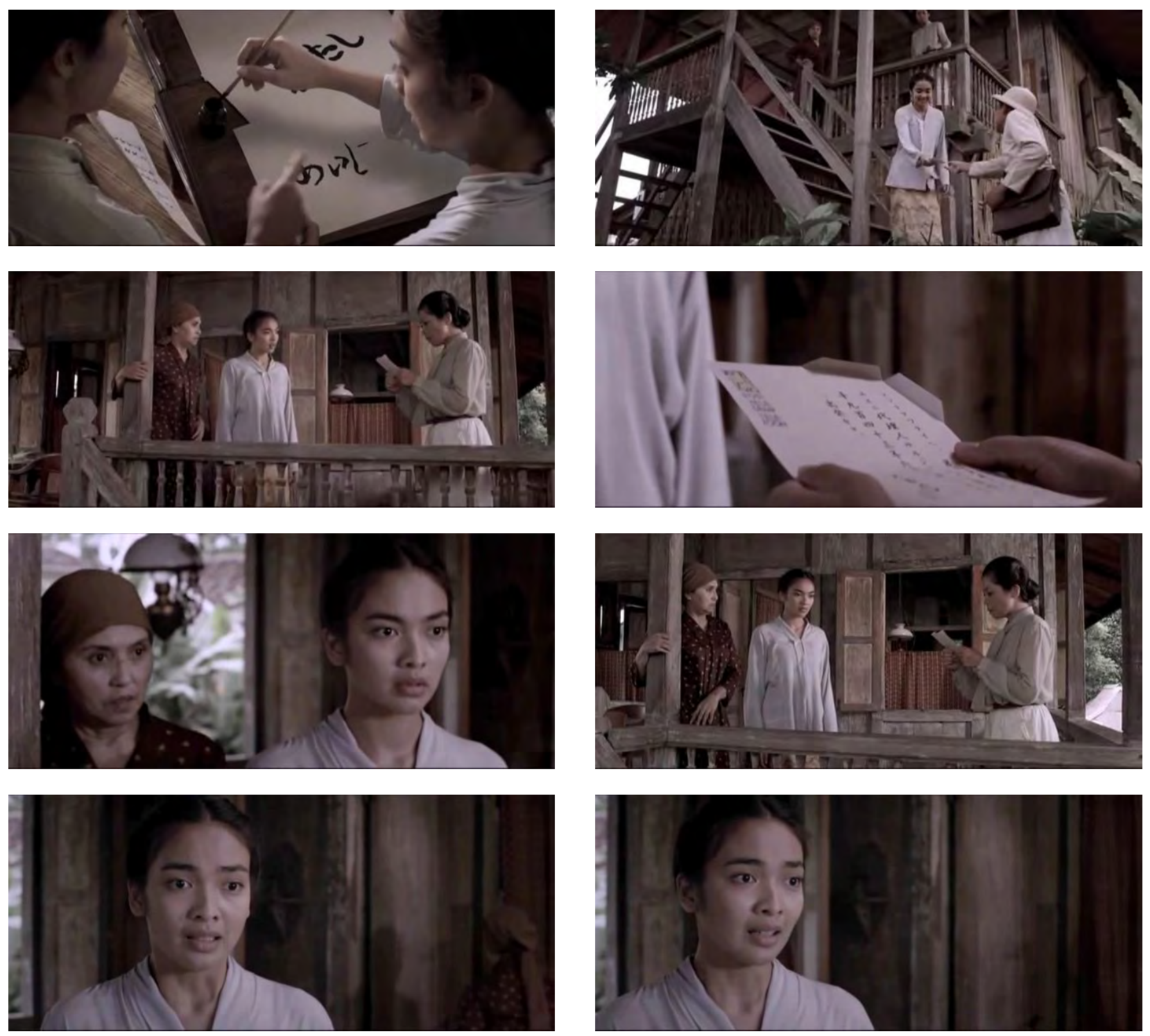

Fatmawati pada saat sedang belajar menulis huruf kanji Jepang dengan seorang guru perempuan Jepang datang petugas pos ke rumah Fatmawati mengantar sebuah telegram yang diterima secara langsung oleh Fatmawati. Ibu Fatmawati bertanya telegram dari siapa yang dijawab tidak mengetahui karena berbahasa Jepang. Fatmawati kemudian meminta bantuan guru perempuan Jepang untuk membacakan isi telegram yang datang dari Soekarno.

Guru Perempuan Jepang : Dari Soekarno. Fatmawati, koma. Nikah dengan diwakili opsirkaris Sardjono, koma, karena pihak mempelai laki-laki tidak bisa hadir, koma, tanggal satu bulan Juni seribu sembilan ratus empat puluh tiga berangkat ke Jakarta, titik.

Fatmawati $\quad:$ [dengan wajah tercengang dan memendam rasa bahagia dengan segaris senyum di wajahnya]

Ibu Fatmawati

: [sambil berlari berteriak ke arah suaminya yang berada di ruang tamu] Pak! Fat nikah!

Ayah Fatmawati

: [dari dalam ruang tamu] Sama siapo?

Ibu Fatmawati

: [VO] sama Bung Karno lah!

[MS] Wajah Fatmawati menunjukkan ekspresi antara terkejut dan bahagia mendengar isi telegram yang baru saja didengarnya. (Soekarno, 2013, Part 2, 00:07:08-00:08:01) 

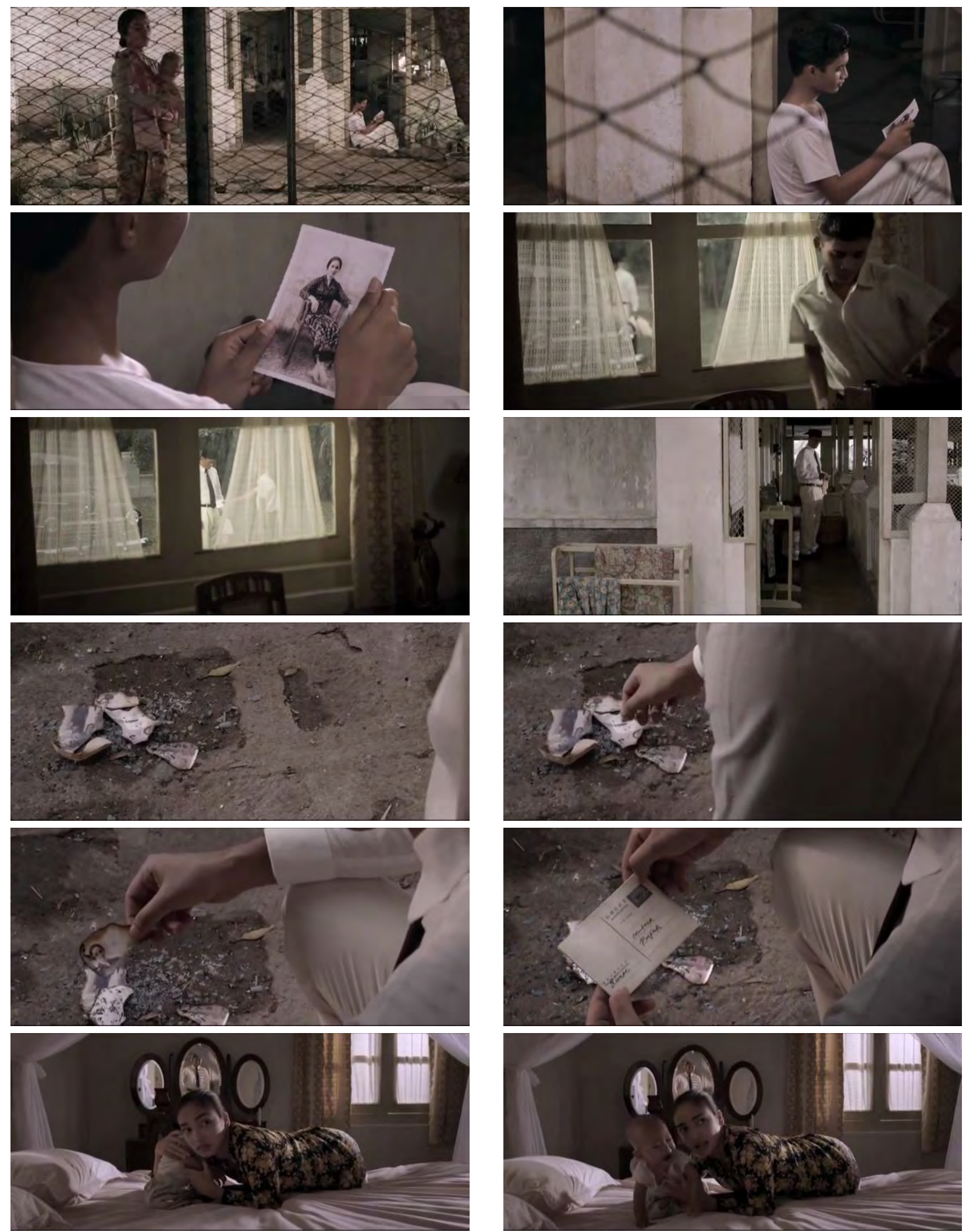

Fatmawati melihat Riwu selalu memandangi foto Inggit Ganarsih. Oleh karena suatu hal, ketika Soekarno tiba di rumah dan berjalan dari mobil, Riwu menemui Soekarno sambil memberikan sepucuk surat kepada Soekarno. Riwu sekaligus berpamitan kepada Soekarno untuk pergi meninggalkan rumah di Pegangsaan Timur. Lantas Soekarno berjalan ke dalam rumah dan menemukan bekas cuilan-cuilan foto Inggit Ganarsih yang terbakar. Ia pun mengambil potongan foto yang masih menyisakan wajah Inggit Ganarsih. Soekarno kemudian menemui istrinya Fatmawati di kamar tidur yang sedang bermain dengan putranya Guntur. Tapi Soekarno tidak bicara hanya memandangi wajah istrinya. Fatmawati yang justru bicara kepada Soekarno.

Fatmawati

: [sambil bermain dengan Guntur memandang Soekarno] Dari seminggu lalu ia selalu melihat foto Inggit. Aku merasa dibanding-bandingkan dengan dia. (Soekarno, 2013, Part 2, 00:18:15-00:20:19) 
Dalam film Soekarno terungkap suatu dialog keinginan tokoh Soekarno menikahi tokoh Fatmawati untuk memperoleh anak, sebagaimana yang diharapkan dari kedua orang tua tokoh Soekarno. Hal yang tidak bisa dipenuhi oleh tokoh Inggit Ganarsih karena usia tokoh Inggit Ganarsih lebih tua beberapa tahun dari usia tokoh Soekarno. Pernikahan tokoh Soekarno dengan tokoh Fatmawati, dalam film Soekarno juga memunculkan konflik antara tokoh Riwu anak angkat tokoh Soekarno dengan tokoh Inggit Ganarsih yang selama ini setia menemani tokoh Soekarno. Tokoh Riwu lebih memilih meninggalkan tokoh Soekarno karena didorong oleh rasa kasih sayangnya kepada tokoh Inggit Ganarsih dan bentuk ketidaksetujuannya kepada tokoh Soekarno yang menceraikan tokoh Inggit Ganarsih. Kondisi ini berlangsung hingga terjadi peristiwa ketika tokoh Soekarno menemukan ceceran potongan bekas foto tokoh Inggit Ganarsih yang dibakar oleh tokoh Fatmawati, meskipun dalam film tidak diperlihatkan aksi
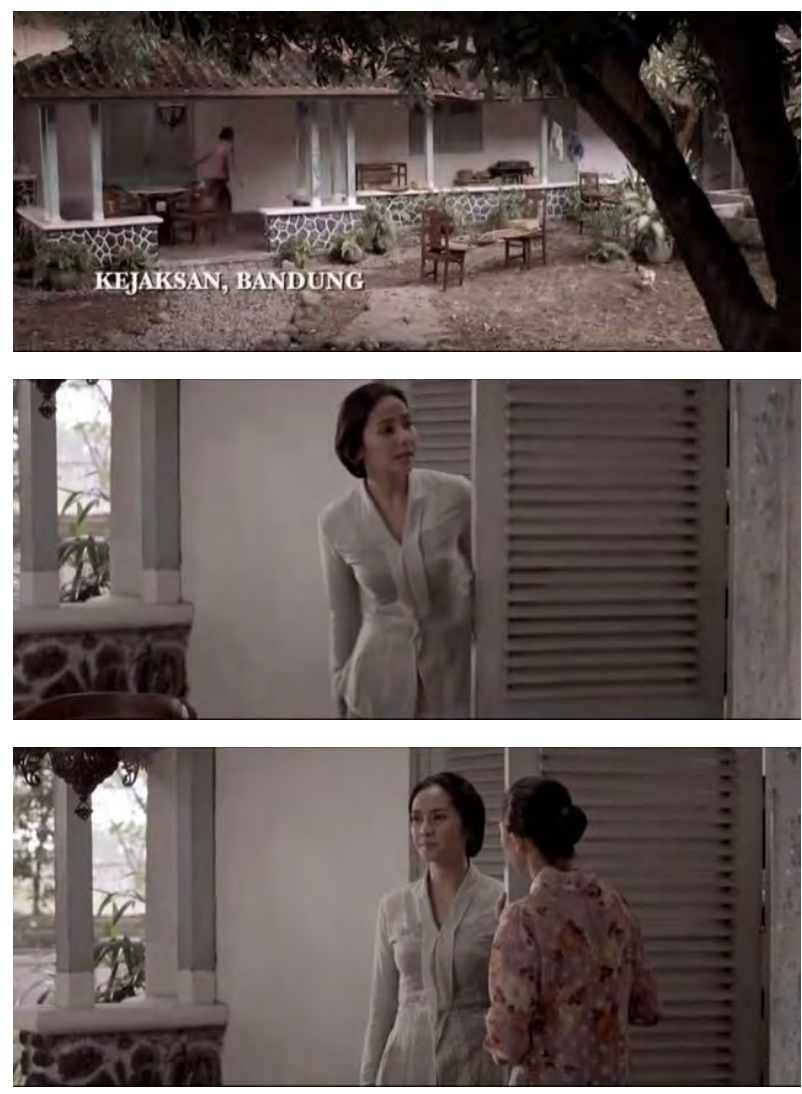

Eneng seorang perempuan muda mendatangi rumah Inggit Ganarsih sambil memanggil-manggil nama Inggit dan mengetukngetuk pintu rumahnya. Perempuan muda itu mengabarkan kepada Inggit bahwa Soekarno ditangkap Belanda di Jogjakarta. membakarnya. Berdasar dialog antara tokoh Fatmawati dengan tokoh Soekarno serta scene pengadegan sebelumnya yang memperlihatkan tokoh Riwu memandangi foto tokoh Inggit Ganarsih, dan wajah kesal ditunjukkan oleh tokoh Fatmawati yang melihatnya, bisa terlihat secara simbolik relevansi dari kasualitas yang resiprokal adegan yang memperlihatkan terjadi konflik antara tokoh Fatmawati dengan tokoh Riwu, anak angkat tokoh Soekarno dengan tokoh Inggit Ganarsih.

Tokoh Soekarno pada saat mengalami penderitaan sebagai konsekuensi garis perjuangan dalam meraih kemerdekaan seperti pemenjaraan di Jogja, penjara Banceuy di Bandung serta pada saat mengalami masa pengasingan dan pembuangan di Ende, Nusa Tenggara Timur hingga Bengkulu, tokoh Inggit Ganarsihlah yang selalu setia menemani dan mendukung seluruh perjuangan tokoh Soekarno. Harta benda milik Inggit Ganarsih bahkan secara suka rela diberikan kepada tokoh Soekarno untuk perjuangan merebut kemerdekaan. Sebuah realitas paradoksal terhadap perempuan. Kesetiaan
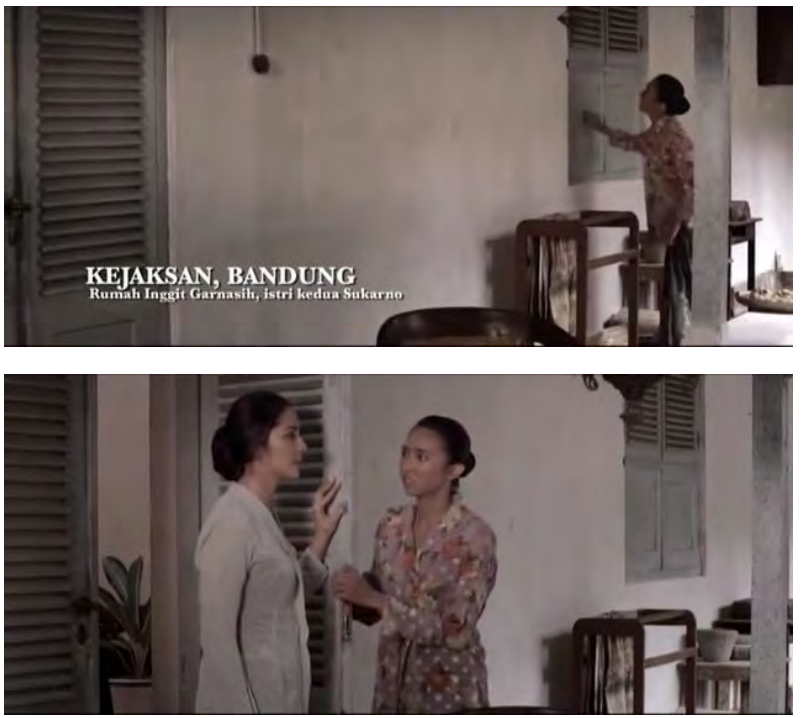

Perempuan Muda

Inggit Ganarsih

Perempuan Muda

: $\mathrm{MS}$ perempuan muda tergesa-gesa sambil mengetuk-ngetuk pintu pintu memanggil-manggil nama Inggit Ganarsih] Ceu'..Ceu'..Ceu’ Inggit. Ceu'...Ceu'....Ceu’ Inggit

: [MS membuka pintu] Ada apa, Neng?

: [MS di depan pintu rumah] Suami Ceuceu ditangkap di Jogja. (Soekarno, 2013, Part 1, 00:19:14-00:19:25) 
yang diberikannya sepenuhnya kepada suaminya, laki-laki yang dicintainya dengan setulus hati, berbalik mengkhianatinya dengan menikahi perempuan lain yang sudah dianggap sebagai anaknya sendiri. Usia tokoh Fatmawati memang seusia anak
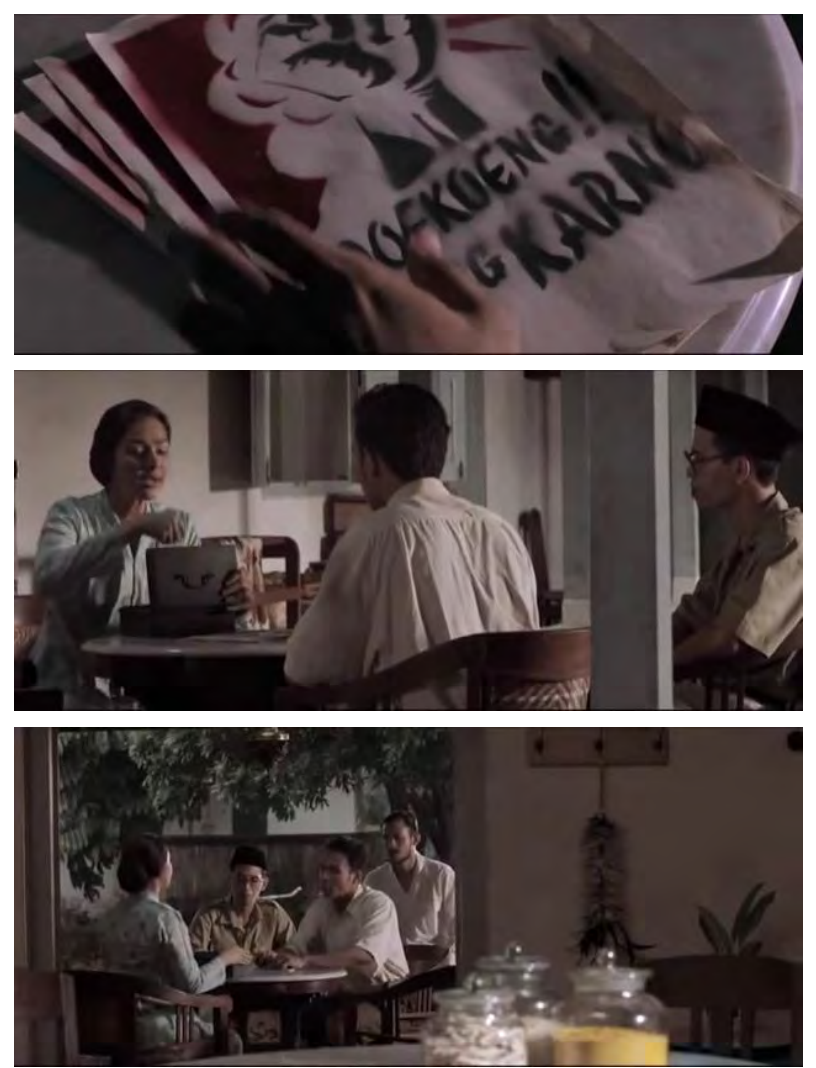

perempuannya, meskipun hanya anak angkat. Pertemuan tokoh Soekarno dengan tokoh Fatmawati sebenarnya juga disebabkan oleh permintaan anak angkatnya untuk tinggal bersama keluarga tokoh Soekarno dan tokoh Inggit Ganarsih.
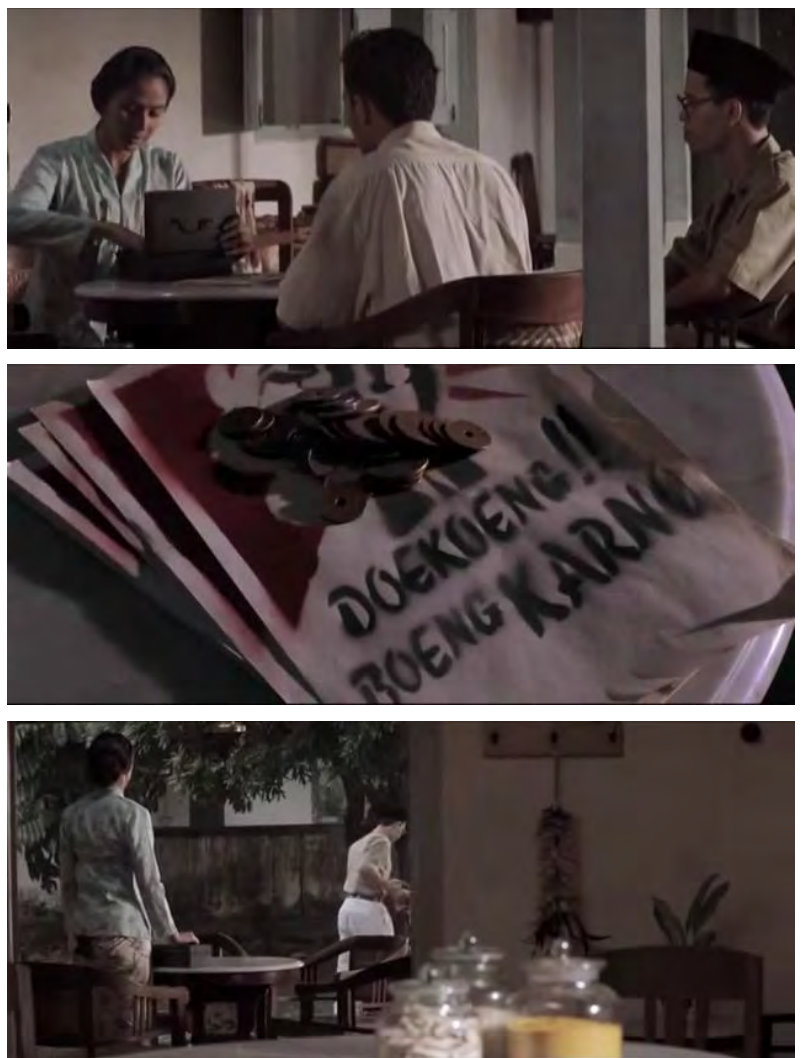

Inggit Ganarsih bertemu dengan sekelompok pemuda dan memberikan dukungan harta bendanya untuk mendukung perjuangan Soekarno.

\section{Pemuda}

Inggit Ganarsih

Inggit Ganarsih

Pemuda
: [Close Up tangan dan lembaran pamflet] Ini Teh bentuk dukungan kami terhadap Bung Karno

: Bagus [MS Lalu membuka kotak uang dan mengambil beberapa kepeng uang logam]

: [MS Inggit memberikan beberapa uang kepeng logam dari tangannya to Close Up beberapa kepeng uang ditaruh di atas pamflet] Mudah-mudahan ini cukup membantu.

: Baik, Teh. Kami akan mendukung Bung Karno mati-matian. Terima kasih.

Para pemuda kemudian meninggalkan rumah Inggit Ganarsih. (Soekarno, 2013, Part 1, 00:20:08-00:20:25)
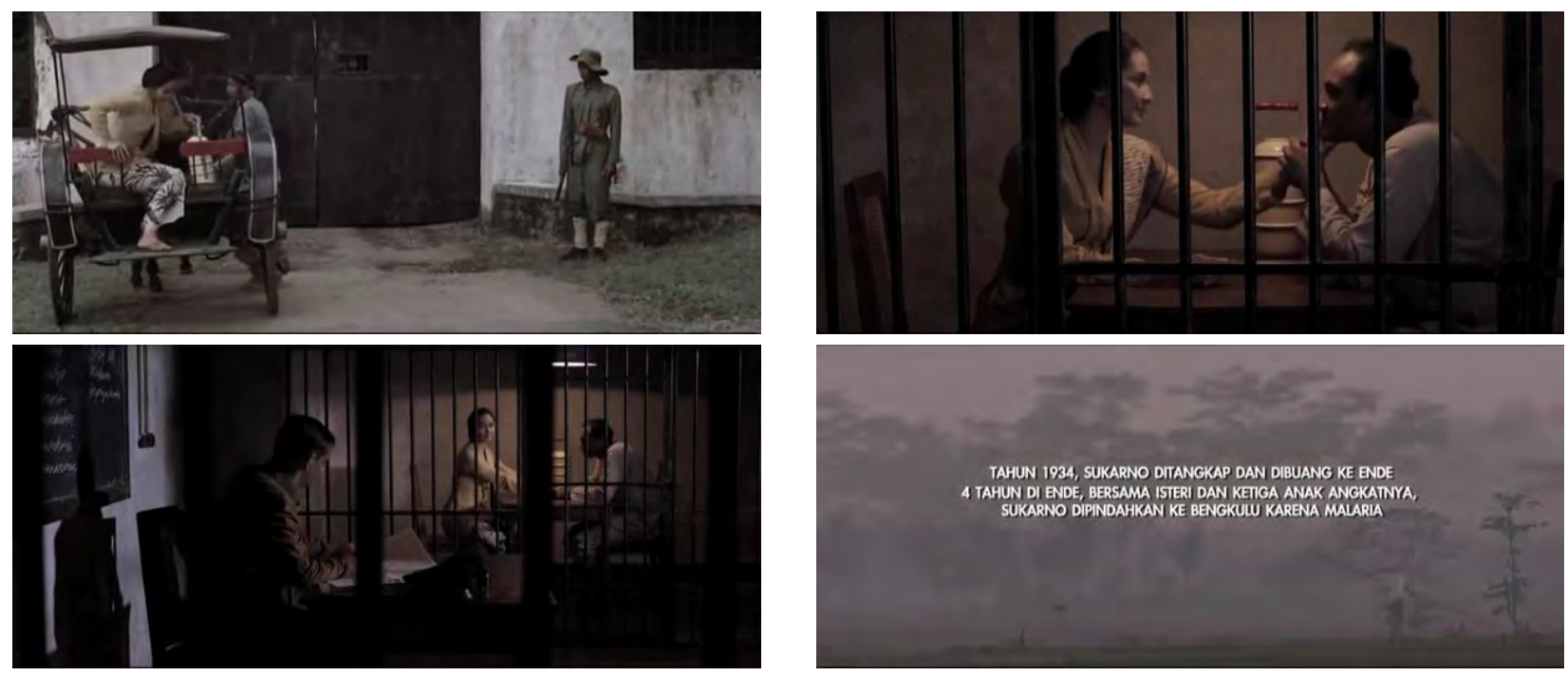

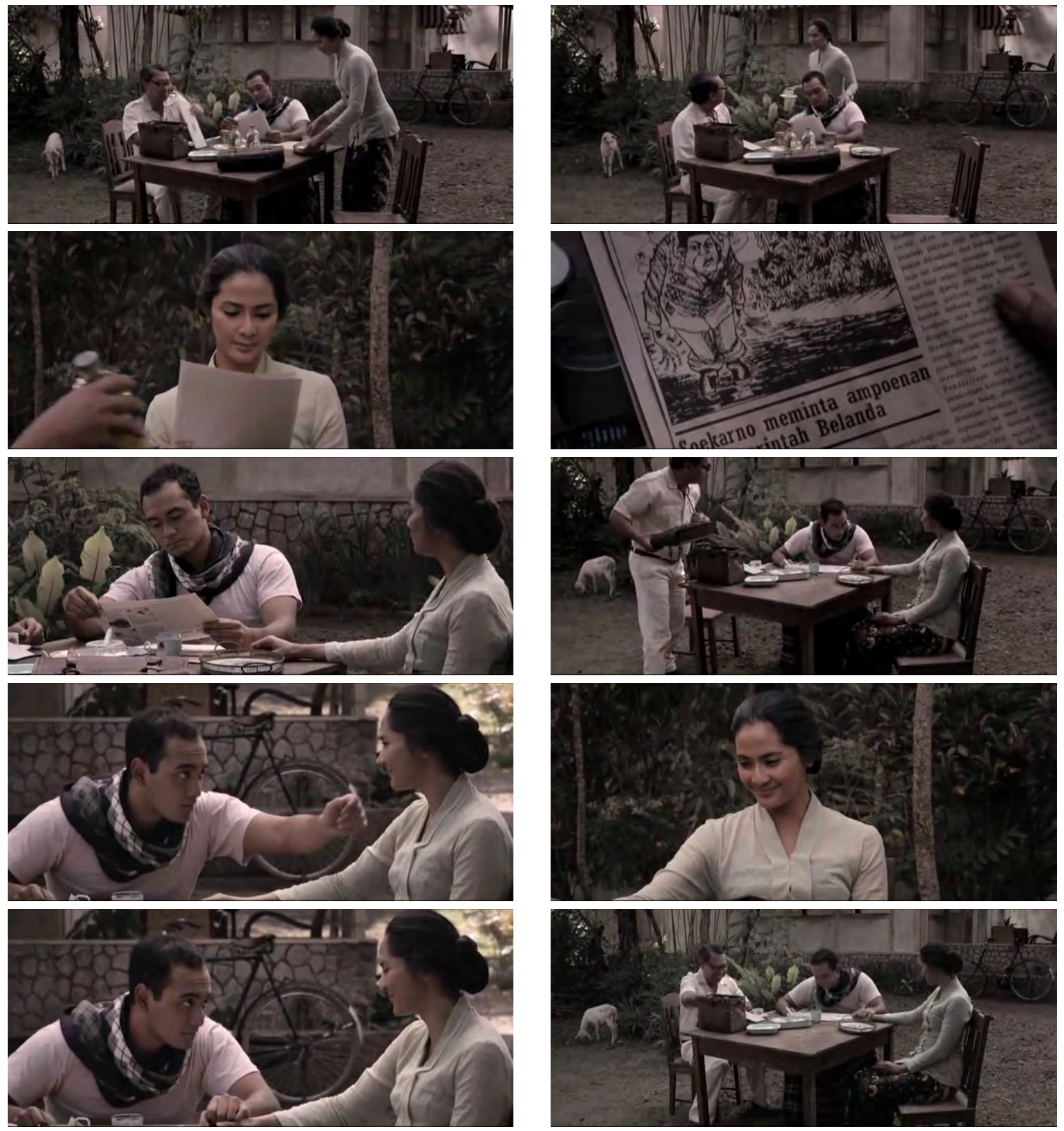

Inggit Ganarsih menemui Soekarno di penjara untuk mendukung perjuangan Soekarno. Inggit Ganarsih juga selalu berada di sisi Soekarno selama dalam pengasingan atau pembuangan Belanda di Ende maupun di Bengkulu. Inggit Ganarsih juga menunjukkan kesetiaan dan kepedulian terhadap Soekarno ketika sakit maupun ketika membaca pamflet-pamflet dan berita surat kabar yang memfitnah Soekarno.

Dokter

Soekarno

Dokter

Inggit Ganarsih

Inggit Ganarsih

Soekarno

Inggit Ganarsih

Soekarno
: Istirahat. Kalau menurut saya, Bung harus menghindari pekerjaan-pekerjaan berat.

: Seperti apa Dokter?

: Ya berpolitik.

: [Sambil menuangkan teh ke dalam cangkir dan memberikan kepada Soekarno dan Dokter] Dokter, Engkoes mah akan tambah sakit kalau jauh dari politik dan rakyatnya. Ya, Koes.

Mereka mah bisa melakukan apa saja atuh, Koes. Aku tidak suka dengan Hatta dan Sjahrir.

Karena mereka menuduhku terlalu menguasaiku.

Karena mereka menuduh aku. Kamu terlalu lemah di hadapan aku. Inggit tidak suka kamu dikatakan seperti itu.

Dalam beberapa hal. Aku sangat menikmati engkau menguasaiku. (Soekarno, 2013, Part 1, 00:20:3200:24:26) 
Data visual dan dialog tersebut menunjukkan bagaimana tokoh Inggit Ganarsih merupakan perempuan hebat yang sangat setia dan mencintai suaminya. Perempuan dengan karakter kuat dan tanpa menyerah mendukung sepenuhnya perjuangan tokoh Soekarno dalam meraih citacita kemerdekaan, meskipun saat tokoh Soekarno memproklamasikan kemerdekaan Indonesia tokoh Inggit Ganarsih bukan lagi istri sah tokoh Soekarno karena sudah diceraikannya. Kualitas "maskulinitas" dalam diri Inggit Ganarsih sebagai seorang perempuan justru menjadi pilar utama dalam mendukung kerasnya perjuangan tokoh Soekarno dalam melawan rintangan untuk meraih kemerdekaan. Kualitas maskulinitas diadopsi oleh tokoh Inggit Ganarsih yang ditunjukkan dengan keberanian mendatangi penjara untuk memberikan dukungan moral dan mentalitas kepada tokoh Soekarno di balik terali besi kolonialis Belanda. Tokoh Inggit Ganarsih menunjukkan rasionalitas dan kemampuan dalam mengambil keputusan mendukung perjuangan tokoh Soekarno dengan memberikan harta benda yang dimilikinya utuk menopang perjuangan tokoh Soekarno. Di balik ketegarannya dan kekuatannya sesungguhnya tokoh Inggit Ganarsih justru tidak menyukai pendapat dari Hatta dan Sjahrir yang memposisikan lakilaki takluk kepada dirinya. Dalam hal ini dapat diartikan bahwa sikap tokoh Inggit Ganarsih menunjukkan bahwa antara laki-laki dan perempuan berkedudukan sama (equality), tidak ada pihak yang dihegemoni atau dikuasai dalam konteks relasi kuasa dalam rumah tangga. Di balik kekuatan dan kesuksesan laki-laki terdapat sosok perempuan yang kuat dan berkarakter. Tokoh Inggit Ganarsih adalah termasuk pribadi tersebut. Hal itu menunjukkan signifikansi dari kode-kode kultural dan politik dari diri tokoh Inggit Ganarsih dalam mendukung perjuangan suaminya, sebagai suami dan pemimpin negeri.

Tokoh Inggit Ganarsih secara sadar memahami pemikiran, jiwa, moralitas, dan komitmen tokoh Soekarno terhadap kemerdekaan dan kecintaannya kepada rakyat Indonesia. Dialog yang sarat dengan substansi makna ditunjukkan oleh tokoh Inggit Ganarsih, saat menjawab saran dari dokter yang memeriksa tokoh Soekarno untuk tidak berpolitik.
Tokoh Inggit Ganarsih justru menegaskan bahwa tokoh Soekarno tidak dapat dipisahkan dari rakyat dan politik. Hal itu menunjukkan bagaimana tokoh Inggit Ganarsih memiliki prinsip rasionalitas dan sifat memahami pentingnya peran dari suaminya terhadap kemerdekaan rakyat Indonesia. Inggit Ganarsih bahkan rela ketika suaminya lebih memilih mencintai rakyat Indonesia dibandingkan dirinya. Pernyataan yang dikemukakan oleh tokoh Inggit Ganarsih menunjukkan bagaimana rasionalitas dirinya tanpa presentasi emosionalitas dirinya sebagai wanita mendukung sepenuhnya apa yang telah dilakukan oleh tokoh Soekarno untuk memerdekaan rakyat Indonesia. Inggit Ganarsih merupakan seorang perempuan yang tegar dan memiliki pribadi yang bisa memahami pentingnya kehadiran tokoh Soekarno bagi negara dan rakyat Indonesia.

Menurut teori kekerasan gender bahwa yang telah dilakukan tokoh Soekarno dengan memadu tokoh Inggit Ganarsih merupakan bentuk serangan atau invasi (assault) terhadap integritas mental psikologis diri tokoh Inggit Ganarsih. Bentuk perlawanan dari praktik hegemoni maskulinitas dan budaya patriarki ditunjukkan oleh tokoh Inggit Ganarsih dengan memutuskan untuk meninggalkan tokoh Soekarno dan memilih tinggal Lengkong Besar di rumah salah satu kenalan baiknya ketika berada di Bandung. Tokoh Inggit Ganarsih sebenarnya sangat terluka hatinya terhadap keputusan tokoh Soekarno untuk menikah lagi dengan tokoh Fatmawati. Keputusan tokoh Soekarno jelas melukai dan menyinggung harga dirinya secara mental psikologis, apalagi perempuan yang dinikahinya sudah dianggap sebagai anak sendiri oleh tokoh Inggit Ganarsih. Inggit Ganarsih tidak tenggelam dalam rasa luka yang berkepanjangan yang akan berpengaruh terhadap mental dan jiwa psikologisnya. Sikap tegar dan menerima keputusan tokoh Soekarno dengan meninggalkannya adalah sikap yang memang diambilnya sebagai konsekuensi dari ketegaran pribadinya.

\section{Simpulan}

Film merupakan media yang mampu menghadirkan realitas teks-teks naratif yang 
terbungkus dalam adegan-adegan dan gambar visual sebagai bentuk simbolisme-simbolisme dari mimetisme yang hadir di tengah masyarakat. Film Soekarno mampu merepresentasikan mimetisme sejarah sebagai komodifikasi media kepada masyarakat, meskipun film tersebut sarat dengan kritik atas perlakuan ketidakadilan pada zamannya. Ketidakadilan yang selalu berwajah perempuan. Ketidakadilan yang dialami oleh perempuan yang mengalami kekerasan seksual dan kekerasan nonseksual, dalam arti kekerasan psikis, bisa dihadirkan sebagai "realitas sosial" yang direpresentasikan sebagai realitas media. Realitas media yang dibangun oleh film Soekarno merupakan hasil pemahaman dari konstruksi fakta-fakta historis yang kemudian direkonstruksi kembali dalam wujud audiovisual oleh Hanung Bramantyo sebagai sutradara film.

Interpretasi terhadap rekonstruksi fakta-fakta historis yang menjadi objek bahasan film Soekarno dengan memaknai imaji visualiasi dari Hanung Bramantyo sebagai sineas dengan menggunakan teori encoding (proses produksi teks) dan decoding (konsumsi teks) Stuart Hall, menemukan suatu penggambaran visual dan adegan-adegan dalam sekuen-sekuen film yang merepresentasikan adanya praktik ketidakadilan gender pada perempuan Indonesia. Praktik ketidakadilan gender yang termanifestasikan dalam wujud kekerasan seksual dan kekerasan psikis pada perempuan karena intervensi dari perilaku kolonialisme fasisme Jepang dan diri tokoh Soekarno terhadap tokoh Inggit Ganarsih.

Pemahaman terhadap produksi makna teks naratif dalam film Soekarno berperan penting untuk menghasilkan pemaknaan atas maknamakna simbolik dari unsur visualisasi yang dialami oleh perempuan Indonesia, sehingga secara fungsi, film menjadi manifestasi dari representasi faktafakta historis maupun realitas sosial yang terjadi pada suatu zaman. Masyarakat sebagai penonton menjadi memiliki atmosfer situasional dan visualisasi peristiwa pada masa itu. James Elkins dalam Budiman dkk. (2013) menyatakan bahwa kajian film jangan mengabaikan unsur visualitas karena kodrat film sebagai media (auido- visual). Apa yang divisualisasikan oleh Hanung Bramantyo terhadap posisi perempuan Indonesia dalam film
Soekarno merupakan wujud dari signifikansi hitorical memory dan collective memory bangsa Indonesia. Tujuannya agar bangsa Indonesia yang hidup pada era pascakolonial senantiasa mengingat bahwa terdapat fakta sejarah tentang ketidakadilan dan pelanggaran hak asasi manusia perempuan Indonesia yang senantiasa harus diingat dan diperjuangkan sebagai suatu mainstream ideologi kepada publik. Retorika ketidakadilan pada perempuan melalui praktik-praktik kekerasan seksual, politik seksual, kekerasan psikis, hingga pemenjaraan seksual digambarkan dengan secara jelas oleh Hanung Bramantyo dalam representasi teks-teks naratif dan visual dalam film Soekarno. Sebuah retorika dan ideologi makna yang senantiasa menimbulkan presentasi objek sebagai pertanyaan besar, mengapa selalu harus perempuan?

\section{Ucapan Terima Kasih}

Rasa terima kasih diucapkan kepada: (1) Dr. Ikwan Setiawan, M.A. yang telah membimbing terkait topik dalam kajian dalam penulisan artikel ini; (2) Fajar Aji, S.Sn., M.Sn. yang telah bersedia membantu diskusi terkait dengan metodologi pemaparan data audiovisual film sebagai bahan kajian dalam penulisan artikel ini sehingga bisa terwujud; (3) Sunarlan, S.S.,M.Si. yang telah membantu dalam memahami fakta-fakta historis pada diri Soekarno dikaitkan dengan film Soekarno yang pada akhirnya dapat membantu dalam menyelesaikan penulisan artikel ini.

\section{Kepustakaan}

Andrew, J. Dudley. 1976. The Major Film Theories: An Introduction. London: Oxford University Press.

Ayawaila, Gerzon R. 2008. Dokumenter dari Ide sampai Produksi. Jakarta: FFTV-IKJ Press.

Budiman, Christian; Abdullah, Irwan; Simatupang, G.R. Lono. 2013. "Retorik dan Makna Ideologi Karya Instalasi dalam Film Opera Jawa Garin Nugroho. RESITAL JURNAL SENI PERTUNJUKAN. Vol. 14 No. 1 Juni 2013: 1-8.

Dzuhayatin, S dan Susi Eja Yuarsi. 2002. Kekerasan 
terhadap Perempuan di Ruang Publik. Yogyakarta: Pusat Studi Kependudukan dan Kebijakan Universitas Gadjah Mada.

Fakih, Mansour. 1997. Analisis Gender dan Transformasi Sosial. Cetakan ke-2. Yogyakarta: Pustaka Pelajar.

Hananta, Elita Primasari. 2013. "Konten Kekerasan dalam Film Indonesia Anak Terlaris Tahun 2009-2011. JURNAL E-KOMUNIKASI. Vol. 1. No. 1 Tahun 2013: 1-12.

Hanung Bramantyo. 2013. Soekarno.[Film]. Jakarta: MVP Picture, Mahaka Picture dan Dapur Film Picture.

Haryatmoko. 2007. Etika Komunikasi: Manipulasi Media, Kekerasan, dan Pornografi. Yogyakarta: Kanisius.

Hikmat, Mahi M. 2011. Metode Penelitian dalam Perspektif Ilmu Komunikasi dan Sastra. Yogyakarta: Graha Ilmu.

Imanjaya, Ekky. 2006. A-Z About Indonesian Film. Bandung: DAR! Mizan.

Kartika, Bambang Aris. 2010. "Ragam Kritik Sastra Feminisme Radikal: Kekerasan Psikis dan Women Trafficking Perempuan dalam Drama Siau Ling Karya Remy Sylado”. JURNAL SEMIOTIKA, 11 (1): 48-59.

2011. "Eksploitasi Concubinage dan Subjek Subaltern: Hegemoni atas Perempuan Indonesia dalam Tinjauan Kritis Pascakolonial dan Feminisme Novel De Winst Karya Afifah Afra”. JURNAL ATAVISME, Vo. 14 No. 1: 51-64.

Koentowijoyo. 2003. Metodologi Sejarah. Edisi ke2. Yogyakarta: Tiara Wacana.

Kompas. 10 Desember 2001.
Kompas. "PM Abe Sesalkan Para Korban PD II". 2 Mei 2015.

La Pona, dkk. 2002. "Menggagas Tempatyang Aman bagi Perempuan: Kasus di Papua”. Yogyakarta : Pusat Studi Kependudukan dan Kebijakan Universitas Gadjah Mada.

Mariana, Ana. 2015. Perbudakan Seksual Perbandingan Antara Masa Fasisme Jepang dan Neofasisme Orde Baru. Jakarta: Marjin Kiri.

Metz, Christian. 1974. A Semiotics of the Cinema: Film Language. New York: Oxford University Press.

Nurudin. 2014. Pengantar Komunikasi Massa. Cetakan kedua. Jakarta: Rajagrafindo Persada.

Siswantoro. 2010. Metode Penelitian Sastra: Analisis Struktur Puisi. Yogyakarta: Pustaka Pelajar.

Sobur, A. 2004. Semiotika Komunikasi. Bandung: Remaja Rosdakarya.

Sofia, A. 2009. Aplikasi Kritik Sastra Feminisme Perempuan dalam Karya-karya Kuntowijoyo. Yogyakarta: Pustaka Pelajar.

Spivak, Gayatri Chakravorty. 1993. "Can the Subaltern Speak?”. Dalam Patrick Williams dan Laura Chrisman (ed). Colonial Discourse and Postcolonial Theory. Hemel Hempstead: Harvester Wheatsheaf.

Soekirno, Dewi Candraningrum. 2006. “GDI, GEM dan Subaltern Perempuan Indonesia", tersedia di www.jurnalperempuan.com/yjp. jpo/?act=artikel\%7C-57\%7CX. Diunduh pada tanggal 27 Januari 2011,

Sumarno, Marselli. 1996. Dasar-dasar Apresiasi Film. Jakarta: Grasindo.

Wineburg, Sam. 2006. Berpikir Historis. Penerjemah Masri Maris. Jakarta: Yayasan Obor Indonesia. 